Estudo longitudinal sobre similaridade, transmissão, e estabilidade de colonização de Estreptococcus mutans em famílias brasileiras 

CASSIA MARIA FISCHER RUBIRA

\title{
Estudo longitudinal sobre similaridade, transmissão, e estabilidade de colonização de Estreptococcus mutans em famílias brasileiras
}

\author{
V. 1 \\ Tese apresentada à Faculdade de Odontologia de \\ Bauru, da Universidade de São Paulo, como parte \\ dos requisitos para obtenção do título de Doutor em \\ Odontologia. \\ Área de concentração: Estomatologia \\ Orientadora: Prof ${ }^{a}$ Dra Odila Pereira da Silva Rosa \\ Co-Orientador: Prof. Dr. Walter A. Bretz
}

BAURU

2007 


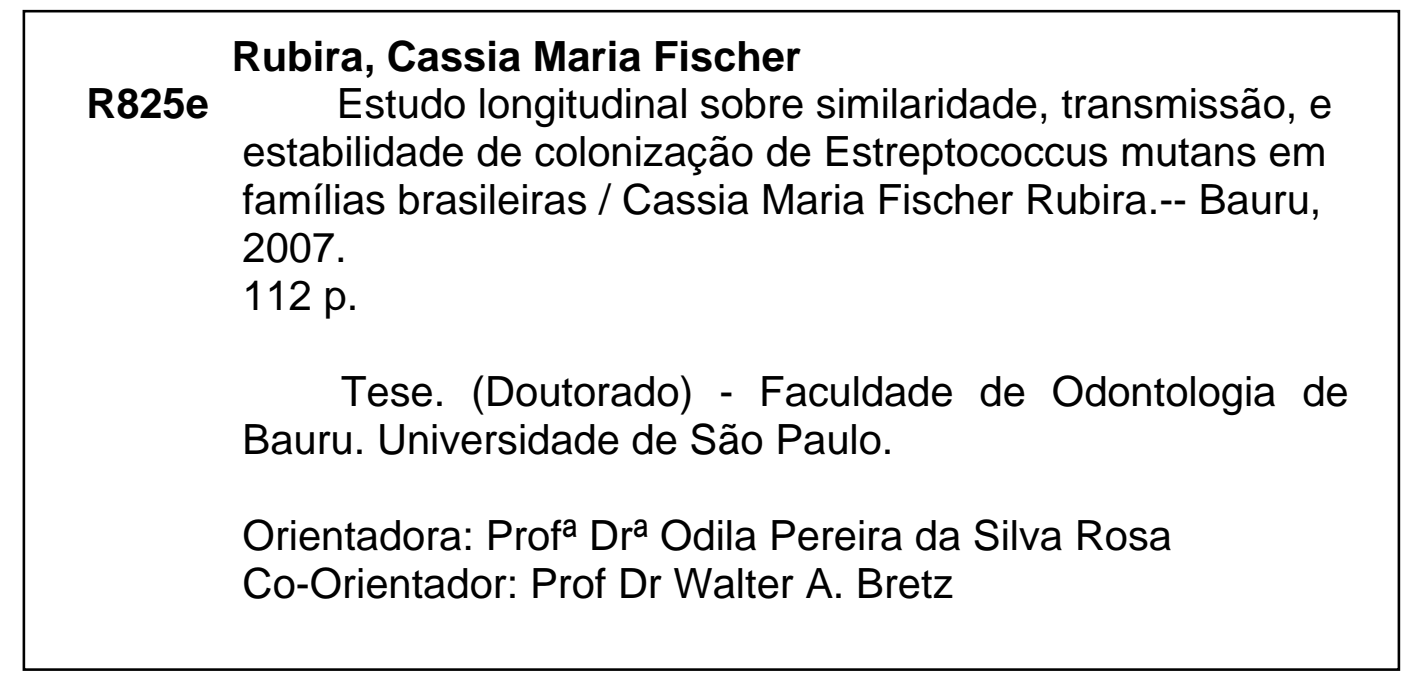

Autorizo, exclusivamente para fins acadêmicos e científicos, a reprodução total ou parcial desta tese, por processos fotocopiadores e outros meios eletrônicos.

Assinatura:

Comitê de Ética: Forsyth Institute IRB (Boston, MA, USA)

Protocolo no: 6-11

Data: August 7, 2007 




\section{DEDICATÓRIA}

À minha filha, Isabella, pela compreensão e ajuda. Aos meus pais, Gabriel e Myrthes que sempre me incentivaram para estudar, aos quais devo, em grande parte, o que hoje sou. Às minhas irmãs, Izabel e Cecília, pelas palavras positivas. Aos meus sobrinhos, Pedro, Miguel, Juliana e Eduardo. À minha avó Izabel. Ao José Augusto. Ao Wilson. Enfim, as pessoas que por mim, depositaram sua confiança. 



\section{AGRADECIMENTOS}

A minha orientadora Prof Dra Odila Pereira da Silva Rosa, pela confiança e a certeza de que eu não a decepcionaria. Ao Prof Dr Walter Bretz, pela confiança em dobro, a minha eterna gratidão. Aos meus dois orientadores, espero ter cumprido parte de um belíssimo trabalho realizado no Projeto Pittsburgh.

Á todos os meus professores desta casa e do curso de doutorado em Estomatologia, que contribuíram na minha formação como pesquisadora e educadora. Em especial, ao Prof Dr José Humberto Damante pela a amizade e paciência, à $\operatorname{Prof}^{\mathrm{a}} \operatorname{Dr}^{\mathrm{a}}$ Ana Lucia Álvares Capelozza pela a alegria e o carinho, ao Prof Dr Luiz Eduardo Montenegro Chinellato pela atenção e a serenidade, aos três meus sinceros agradecimentos e eterna gratidão.

Aos demais professores da Cirurgia e da Estomatologia: Profs. Drs. Paulo Sérgio Perri de Carvalho, Eduardo Sant'Ana, Osny Ferreira Júnior, Júlio de Araújo Gurgel.

À Profa Dra Maria Fidela de Lima Navarro e ao Prof. Dr. José Carlos Pereira pelo apoio.

Ao Prof. Dr. José Roberto Pereira Lauris pelas inúmeras orientações quanto à análise estatística.

Aos funcionários da Estomatologia e da Cirurgia, Josieli, Elza, Luciana, Camila, Fernanda, Roberto, Roque e Walderez. Em especial à Marília Gião, minha companheira.

I also thank Dr Anne Tanner and my Forsyth's friends, Eleni, Jennifer, Charles, Mohamed and Lila.

Aos amigos de turma de Doutorado, Luís Fernando, Eduardo, Flávio, Cláudio e Fernando. Aos colegas de Pós-Graduação, Renato, Marcelo, Etiene, Carla, Zanda, Melissa, Josiane, Tadeu, Renata, Daniele, Gustavo, Letícia, Marta, Ellen, Manoela, Camila, Marcelo, Gabriel, Ana Raquel, Adilson, Angélica e o Augusto.

À secretaria de pós-graduação da Faculdade de Odontologia de Bauru. Aos funcionários do Serviço de Biblioteca e Documentação "Prof Dr Antônio Gabriel Atta". 

"For all those times you stood by me For all the truth that you made me see For all the joy you brought to my life For all the wrong that you made right For every dream you made come true For all the love I found in you I'll be forever thankful" 



\section{RESUMO}

O objetivo deste estudo foi investigar longitudinalmente a transmissão de Streptococcus mutans em um grupo de famílias brasileiras de baixa renda. Um critério de inclusão importante foi o de todos os adultos conviverem na mesma casa com a criança. Participaram da pesquisa 14 mães, pais e crianças e 8 avós. Amostras de saliva das crianças foram coletadas em quatro visitas durante 22 meses, para pesquisa de S.mutans. Foram positivas apenas 8 crianças, que tiveram os seus isolados e os isolados de suas famílias identificados pelo método de hibridização DNA-DNA. Um total de 506 isolados de S.mutans foi genotipado pelo método de AP-PCR, usando o primer OPA-02. Foram detectados 20 genótipos diferentes nas 8 famílias, variando de 1 a 5 nos adultos e 1-2 nas crianças. Todas as mães e alguns pais e avós compartilharam genótipos com as crianças. Em todas as famílias foram encontrados genótipos homólogos nos adultos. Alguns genótipos foram estáveis, e outros, se perderam, mas o compartilhamento pode favorecer a contínua reinfecção. Três crianças desenvolveram cárie no período. O encontro de genótipos de cada membro da família na criança e o compartilhar de genótipos nos adultos, sugerem uma reavaliação de modelos preventivos antimicrobianos focalizados apenas na figura materna.

Palavras-chave: Streptococcus mutans; AP-PCR; Transmissão 



\begin{abstract}
The objective of this study was to investigate in a longitudinal study the transmission of Streptococcus mutans in Brazilian families of a low socioeconomic status. An important entry criterion for the study was to include all members of a household in the study. The study cohort was comprised of 14 mothers, fathers and children and 8 grandmothers. Saliva samples were collected for S. mutans analysis in 4 visits during 22 months. Only eight children were positive for $S$. mutans by employing DNA-DNA hybridization that was also applied to household members. A total of 506 isolates of S. mutans were genotyped by AP-PCR with the primer OPA-02. Twenty genotypes were detected in 8 families ranging from 1 to 5 in the adults and 1-2 in the children. All mothers and some fathers and grandmothers shared similar genotypes with the children. In all families homologous genotypes were encountered among adults. Some genotypes were stable, and others were lost although sharing a similar environment may favor additional transmission episodes. Three children developed decay during the study period. The fact that children shared genotypes from all household members suggest that reevaluation of preventive methods aimed at suppressing S. mutans infections should include additional family members and not only the mothers.
\end{abstract}

Key words: Streptococcus mutans; AP-PCR; Transmission 



\section{LISTA DE ILUSTRAÇÕES}

Figura 1 - Ciclos do termociclador, programado segundo SAARELA et al 1996

Figura 2 - Exemplo de um Checkerboard usado para detectar 8 espécies bacterianas em isolados de algumas crianças. As linhas verticais contêm as sondas das espécies indicadas abaixo na figura. As linhas horizontais possuem as amostras dos isolados das crianças. As duas últimas linhas horizontais estão os controles padrões $10^{5}$ e $10^{6} \mathrm{UFC} / \mathrm{ml}$

Figura 3 - Fotografia do gel de agarose, onde os produtos de reação de amplificação com o iniciador arbitrário de isolados de S.mutans da família 2 foram submetidos à corrida eletroforética. Linha 1 peso molecular (M) utilizado foi DNA 1 kpb; linhas 1 a 7 isolados da criança (linhas 2 e 3, V2; linhas 4 e 5, V3; linhas 6 e 7, V4); linhas 8 a 11 - isolados da mãe (linha 8, V1; linha 9, V2; linhas 10 e 11, V4); linhas 12 a 15 - isolados do pai (linhas 12 e 13, V1; linhas 14 e 15, V2); Linhas 16 a 19 - isolados da agregada (linhas 16 e 17, V1; linhas 18 e 19, V2)

Figura 4 - Transmissão intrafamilial indicado pela similaridade dos genótipos da Tabela 8 



\section{LISTA DE TABELAS}

Tabela 1 - Características clínicas e escores de EM das 14 Famílias

Tabela 2 - Médias e desvios-padrão das características clínicas e escores de EM dos adultos das 14 famílias

Tabela 3 - Número de dentes irrompidos, ceos e escores de EM nas 14 crianças

Tabela 4 - Correlação entre o número de dentes e o momento de detecção (MD) inicial de EM pelo teste de Spearman*

Tabela 5 - Comparação dos índices CPOS e escores de EM dos pais de crianças com e sem cárie pelo teste de Mann Whitney*

Tabela 6 - Hábitos de risco $(n=4)$ dos adultos das famílias de crianças com e sem cárie

Tabela 7 - Total de isolados de Streptococcus .mutans genotipados nos membros das 8 famílias

Tabela 8 - Distribuição dos genótipos dos Streptococcus mutans identificados durante as visitas

Tabela 9 - Estabilidade dos genótipos nos membros das 7 famílias

Tabela 10 - Transmissão dos genótipos das 7 famílias

Tabela 11 - Encontro de genótipos em um ou associação de membros das

60 8 famílias 



\section{LISTA DE ABREVIATURAS E SIGLAS}

AP-PCR - Arbitrarily primed Polymerase Chain Reaction (Arbitrarily primed Polymerase Chain Reaction)

$\mathrm{BHI}$ - Brain Heart Infusion

Checkerboard DNA-DNA Hybridization - Painel de hibridização DNA-DNA

CPOS - número de superfícies cariadas, perdidas e obturadas nos dentes

DNA Fingerprinting - Impressão Digital Genômica do DNA

EM - Estreptococos mutans

IG - índice gengival

L - Lactobacillus

RAPD - Random amplification of polymorphic DNA (Polimorfismo no comprimento de DNA amplificado ao acaso)

$p$ - nível de significância

$p b$ - pares de base

PCR - Polymerase Chain Reaction (Reação em Cadeia de Polimerase)

Primer - oligonucleotídeos

REA - restriction enzyme analysis (Análise com enzimas de restrição)

RFLP - Restriction fragment length polymorphism (Polimorfismo no comprimento de fragmentos de restrição do DNA)

r.p.m - rotações por minuto

SB-20 - Agar sacarose bacitracina

UFC - unidade formadora de colônia

UPGMA - unweighted pair-group method using arithmetic averages (análise das medias aritméticas de grupos não-ponderados) 



\section{LISTA DE SÍMBOLOS}

cm - centímetros

$\mu \mathrm{l}$ - microlitro

$\mathrm{ml}$ - mililitro

mg - micrograma

ng - nanograma

$\mathrm{mM}$ - milimolar

$\mu \mathrm{g} / \mathrm{M}$ - micro

\pm - desvio-padrão

$\mathrm{U} / \mathrm{ml}$ - Unidade por mililitro

○.C - grau Celsius

pH - potencial hidrogeniônico' 



\section{SUMÁRIO}

1 INTRODUÇÃO 26

2 REVISÃO DA LITERATURA 29

3 PROPOSISÃO 38

MATERIAL E MÉTODOS

4.1 População $\quad 40$

4.2 Exame clínico e Questionário 41

4 4.3 Exame bacteriológico e isolamento de EM da saliva 41

4.4 Identificação dos estreptococos mutans $\quad 42$

4.5 Genotipagem dos Streptococcus mutans por AP-PCR 44

4.6 Análise Estatística $\quad 47$

RESULTADOS

$5 \quad 5.1$ Dados clínicos e quantificações de EM 49

$\mathbf{5 . 2}$ Identificação e genotipagem dos estreptococos mutans $\mathbf{5 5}$

6 DISCUSSÃO 63

7 CONCLUSÕES $\quad 71$

REFERÊNCIAS BIBLIOGRÁFICAS

ANEXO 1 85

ANEXO 2

$\begin{array}{ll}\text { ANEXO } 3 & 105\end{array}$ 

1. Introdução 


\section{INTRODUÇÃO}

Os estreptococos mutans (EM) constituem um grupo de cocos Gram positivos bioquìmica, antigenica e geneticamente heterogêneo, do qual fazem parte, entre outros, Streptococcus mutans e Streptococcus sobrinus, os principais responsáveis pela cárie dental humana (LOESCHE, 1986).

O requisito básico para a aquisição e estabelecimento desses microrganismos é a irrupção dos primeiros dentes decíduos, uma vez que necessitam de superfícies não descamativas para se implantar (BERKOWITZ, JORDAN, WHITE, 1975; CARLSSON, GRAHNEN, JONSSON, 1975), tendo sido observado que, quanto mais precocemente ocorrer a colonização oral por EM, maior o risco de desenvolvimento de cárie na dentição decídua (ALALUUSUA, RENKONEN, 1983; KOHLER et al., 1988; FUJIWARA et al., 1991). Por essa razão existe uma preocupação quanto ao momento da aquisição inicial e a fonte desses microrganismos.

A colonização pelos EM ocorre num período definido por CAUFIELD et al. (1993) como "janela da infectividade", dos 19 aos 31 meses de vida. Esse período pode variar, conforme o autor, sendo mais precoce (MATTOS-GRANER et al., 1998; KLEIN et al., 2004), ou mais tardio (EMANUELSSON, LI, BRATTHALL, 1998). REDMO EMANUELSSON, THORNQVIST, 2001 sugeriram que a criança que não for colonizada até os três anos pode permanecer livre por anos.

A mãe parece ser a principal fonte de EM para a infecção dos filhos, pois na maioria das vezes é sua principal cuidadora (BERKOWITZ, JONES, 1975; LI, CAUFIELD, 1995; ALALUUSUA et al., 1996; EMANUELSSON, LI, BRATTHALL, 1998; REDMO EMANUELSSON, WANG, 1998). Dados experimentais já demonstraram que mães com altas concentrações de EM salivares tendem a ter crianças altamente infectadas, ocorrendo o inverso com mães com baixas concentrações (KOHLER, BRATTHALL, 1978; KOHLER, BRATTHALL, KRASSE, 
1983; CAUFIELD, CUTTER, DASANAYAKE, 1993). Essas observações tornaram-se a base de estudos que buscam interferir com a transmissão de EM de mãe para filho diminuindo os níveis salivares de EM nas mães (KOHLER et al., 1982; KOHLER, BRATTHALL, KRASSE, 1983; TENOVUO et al., 1992; CAUFIELD, CUTTER, DASANAYAKE, 1993; KOHLER, ANDRÉEN, 1994). Entretanto, existem outras fontes de infecção (BERKOWITZ et al., 1975; 1980; CAUFIELD, WALKER, 1989; CAUFIELD, CUTTER, DASANAYAKE, 1993; LI, CAUFIELD, 1993; REDMO EMANUELSSON, WANG, 1998; SPOLIDORIO et al., 1993; KLEIN et al., 2004; ERSIN et al., 2004; HAMES-KOCABAS et al., 2006).

Para identificar corretamente a fonte de infecção e o efeito de medidas preventivas, é preciso saber reconhecer o S.mutans que se pretende eliminar. Nessa tarefa foram usados vários métodos, como testes bioquímicos, bacteriocinotipagem e sorotipagem (MASUDA et al., 1979), mas as modernas técnicas moleculares aprimoraram a identificação e quantificação dos microrganismos, permitindo aos pesquisadores melhor compreensão sobre a composição da microbiota bucal (SOCRANSKY et al., 2004). A técnica de hibridização DNA-DNA, por exemplo, permite a determinação simultânea da presença e da quantidade de espécies bacterianas em amostras clínicas múltiplas ou únicas (SIQUEIRA et al., 2001). Uma técnica que vem sendo largamente utilizada na identificação é a AP-PCR, reação em cadeia da polimerase com primers arbitrários. Trata-se de técnica relativamente fácil e rápida de executar, comparada à técnicas mais elaboradas para as quais é necessário o conhecimento prévio da seqüência de DNA da bactéria alvo (SAARELA et al., 1996).

No Brasil, AZEVEDO, ZELANTE (1994), usando bacteriocinotipagem, e SPOLIDORIO et al. (2003), com AP-PCR, realizaram estudos transversais com famílias, tendo observado o compartilhamento de genótipos homólogos de crianças e seus familiares. Estudo longitudinal completo, pesquisando similaridade, estabilidade e diversidade genotípica, foi realizado por KLEIN et al. (2004), em pares de mães e filhos que ficavam em creches. Pela importância do tema, no que diz respeito a medidas preventivas, são necessárias informações longitudinais adicionais sobre a aquisição, estabilidade e compartilhamento de genótipos, em famílias de baixa renda cujos primogênitos sejam cuidados em casa, no período de aquisição inicial. 
2. Revisão de Literatura 


\section{REVISÃO DE LITERATURA}

O início e desenvolvimento da cárie dental dependem da quantidade e qualidade do biofilme, presença de carboidratos (composição, freqüência e quantidade) e da resistência da superfície do dente à adesão dos EM. O aumento do nível de EM e lactobacilos está intimamente associado à ingestão de carboidratos, pois como organismos acidúricos, sobrevivem ao aumento da acidez na placa quando comparados aos demais organismos menos ácido-resistentes. Conseqüentemente à elevação do número de EM e lactobacilos, aumenta a probabilidade de infecção dos dentes vizinhos, especialmente em presença de sacarose, que favorece a adesão inicial dos EM à superfície dos dentes (VAN HOUTE, 1993). Outros fatores como a saliva, exposição ao flúor, higiene bucal, idade, influência familiar, condição sócio-econômica e susceptibilidade do indivíduo são coadjuvantes no desenvolvimento da cárie, podendo modular a qualidade e quantidade do biofilme e aumentar ou diminuir a resistência das estruturas dentais (LOESCHE, 1986; ALALUUSUA et al., 1994).

Os EM constituem um grupo heterogêneo de microrganismos classificados em 7 espécies e 8 sorotipos: S. cricetus (sorotipo a), S.mutans (sorotipos c ,e , f), S.sobrinus (sorotipos d, g), S.macacae (sorotipo c), S.downei (sorotipo h) e S. ferus (sorotipo c). O sorotipo $\mathrm{k}$ foi identificado mais recentemente (NAKANO et al., 2004) e parece sobreviver mais tempo na circulação sanguínea humana. No homem, os EM prevalentes são os Streptococcus mutans, com o sorotipo c correspondendo de 70 a $100 \%$ dos isolados, seguidos do Streptococcus sobrinus (LOESCHE, 1986).

A infância é um importante período para o futuro da saúde bucal no indivíduo, daí o interesse em determinar o momento, o estabelecimento e a fonte de transmissão dos EM na boca. Durante este período os dentes decíduos irrompem e os microorganismos os colonizam. No primeiro ano de vida, os EM podem ser ou 
não detectados ou estar provisoriamente presentes na boca de infantes (CARLSSON et al.,1970; 1975; BERKOWITZ et al., 1975; 1980; MASUDA et al., 1979; ALALUUSUA, RENKONEN, 1983; FUJIWARA et al., 1991). Inicialmente, as crianças abrigam baixos níveis de EM no biofilme e a colonização é transitória (MASUDA et al., 1979; DAVEY, ROGERS, 1984; ALALUUSUA et al., 1996).

O período de aquisição dos EM é um dos fatores chave para melhor entendimento da evolução e do desenvolvimento do processo da cárie, pois quanto mais precocemente a criança for por eles colonizada, maior a chance de desenvolvimento da doença (KOHLER et al., 1978; 1988; ALALUUSUA, RENKONEN, 1983). Contudo, os limites do período de aquisição continuam indefinidos, em face das diferenças reais entre populações ou métodos de amostragem e de detecção. MASUDA et al. (1979) sugerem que o período de aquisição inicial ocorra entre os 13 e os 31 meses de idade da criança. CAUFIELD, CUTTER, DASANAYAKE, em 1993, criaram a hipótese da "Janela de Infectividade" para EM, segundo a qual a aquisição tem lugar entre os 19 e 31 meses de idade. KARN et al.(1998) apontam o período dos 8 aos 15 meses, enquanto TEDJOSASONGKO, KOZAI (2002) relatam uma variação maior no período de aquisição, dos 8 aos 52 meses. Em média, a aquisição inicial é observada aos 26 meses e pelo menos nos primeiros 5 anos de vida (CAUFIELD, CUTTER, DASANAYAKE, 1993; LI, CAUFIELD, 1995). Em crianças brasileiras, a aquisição inicial ocorre mais precocemente, aos 15,4 $\pm 2,12$ meses para S.mutans, e 17,63 \pm 3,56 meses para S. sobrinus (KLEIN et al., 2004).

A detecção de EM aumenta com a idade e com o número de dentes e áreas retentivas em suas superfícies (CARLSSON et al., 1975; MASUDA et al., 1979; ALALUUSUA, RENKONEN, 1983; KLEIN et al., 2004). A presença de superfícies não-descamativas parece ser essencial para a colonização (CARLSSON et al., 1969; 1970; BERKOWITZ, JORDAN, WHITE, 1975; BERKOWITZ, TURNER, GREEN 1980). Entretanto, há evidências de que os EM podem ser encontrados antes da erupção dos dentes (MILGROM et al., 2000). TANNER et al. (2002) detectaram EM na língua de $33 \%$ de bebês edêntulos, com forte relação com a presença da espécie no adulto.

Conforme demonstrado por KOHLER et al. (1978; 1988), a transmissão de EM se dá através de objetos contaminados por saliva. Em seu estudo, a infecção ocorreu pelo compartilhamento de utensílios como copo, colher que o adulto, 
principalmente a mãe, levava à boca, em questão de horas. Daí a conclusão de que a fonte natural para a infecção da criança é o indivíduo com quem tem mais contato. Os autores demonstraram também que a chance da criança se infectar é baixa quando o cuidador principal (mãe ou outro) abrigar nível inferior a 100.000 S.mutans/ml na saliva.

VAN HOUTE, GREEN (1974) sugeriram que a transmissão de bactérias entre indivíduos deve-se essencialmente a fatores de afinidade bacteriana e ao número de UFC (unidades formadoras de colônias) disponíveis para a aderência, o que inclui, por exemplo, a freqüência de transferência, fatores do hospedeiro que interferem na aderência ou crescimento bacteriano, sobrevivência bacteriana durante a transferência, e tipo de dieta do hospedeiro. Esses fatores, biológicos, bem como os relacionados a hábitos e estilo de vida podem ser diferentes em diferentes populações e países.

A identificação individual das cepas de EM isoladas das crianças é essencial para determinar a fonte de infecção. Para tanto, a comparação entre cepas de crianças e conviventes tem sido realizada com base em características fenotípicas, usando métodos como a bacteriocinotipagem (BERKOWITZ, JORDAN, WHITE, 1975; MASUDA et al.,1979; DAVEY, ROGERS, 1984; AZEVEDO, ZELANTE, 1994; GRONROOS et al., 1998) e a sorotipagem (BERKOWITZ et al., 1975; MASUDA et al., 1979; LI et al., 2001), bem como em características genotípicas, investigadas através da determinação de plasmídios em EM (CAUFIELD et al., 1988), ou de técnicas que analisam os modelos das bandas de digeridos do DNA cromossômico por endonucleases de restrição, ou impressão digital de DNA cromossômico - CDF (chromosomal DNA fingerprinting) (CAUFIELD, WALKER, 1989; KULKARNI, CHAN, SANDHAM, 1989; LI, CAUFIELD, 1995; 1998; REDMO EMANUELSSON, WANG, 1998; EMANUELSSON, LI, BRATTHALL, 1998; KOZAI et al., 1999; EMANUELSSON, THORNQUIST, 2001; TEDJOSASONGKO, KOZAI, 2002; LINDQUIST, EMILSON, 2004); ou estudam o polimorfismo de comprimento dos fragmentos de restrição - RFLP (restriction fragment length polymorphism) (MATTOS-GRANER et al. 2001); ou fazem a ribotipagem (SAARELA et al., 1993; ALALUUSUA et al., 1994;1996; GRONROOS et al., 1998), ou ainda, a reação em cadeia da polimerase com iniciadores ("primers") arbitrários - AP-PCR (arbitrarily primed-polymerase chain reaction) (SAARELA et al., 1996; LI, CAUFIELD, 1998; LI et al., 2001; SPOLIDORIO et al., 2003; ERSIN et al., 2004; 
KLEIN et al., 2004, LI et al., 2005). Sem dúvida, os métodos baseados nas características genotípicas são mais acurados.

Dentre as técnicas de genotipagem, destaca-se a AP-PCR. Trata-se de um método rápido, com economia de tempo e de recursos laboratoriais, que pode ser usado na identificação genômica polimórfica nos estudos epidemiológicos e taxonômicos (WELSH, MACCLELLAND, 1990; LI, CAUFIELD, 1998). Na comparação entre técnicas, os resultados da AP-PCR correlacionaram-se bem com a ribotipagem, indicando tratar-se de método adequado quando se investiga grande número de isolados de EM (SAARELA et al., 1996).

LI; CAUFIELD (1998) também encontraram excelente concordância entre o fingerprinting de DNA cromossômico e AP-PCR. No estudo de 14 isolados de S.mutans por AP-PCR e fingerprinting de DNA cromossômico, esta última mostrou maior capacidade de distinção entre os padrões genotípicos do que técnica de APPCR, mas o nível de discriminação desta comparou-se favoravelmente com o fingerprinting de DNA. Na avaliação da similaridade intrafamilial, a técnica de APPCR apresentou resultado semelhante ao do fingerprinting de DNA, quando da comparação dos isolados de 5 pares de mãe-filho com padrões genotípicos idênticos, 5 pares mãe-filho com padrões não idênticos e de 5 pais, demonstrando que a AP-PCR pode distinguir homogeneidade e heterogeneidade de genótipos de EM em famílias. Na comparação entre as duas técnicas, o alto valor de kappa $(K=0.867, \quad p<0,001)$ indicou excelente concordância entre ambas. Quanto à reprodutibilidade, a AP-PCR demonstrou ser uma técnica precisa, com bom desempenho. Em poucos casos a AP-PCR pareceu menos capaz que o fingerprinting em discriminar 40 cepas de S.mutans. Por essa razão, os autores sugerem, em casos de aparente homologia usando AP-PCR, confirmá-la com um segundo primer ou pelo fingerprinting de DNA cromossômico.

De 40 primers estudados na AP-PCR, o primer OPA-02 (OPERON Technologies Inc.), com 10 nucleotídeos - 5'-TGCCGAGCTG e 70\% de bases G+C foi o que exibiu o maior potencial discriminador para S.mutans (LI, CAUFIELD, 1998). A capacidade da AP-PCR com OPA-02 diferenciar S.mutans de S.sobrinus foi comparável à do CDF (LI et al., 2001). SAARELA et al. (1996) empregaram o primer OPA-05, na AP-PCR para S.mutans, e o OPA-13, para o S.sobrinus. De modo geral, os autores que estudam similaridade empregam um primer, como o OPA-02 (LI et al., 2005), o OPA-05 (ERSIN et al., 2004), o OPA-13 (SPOLIDORIO et al., 2003), ou 
dois primers, como o OPA-02 e OPA-13 (KLEIN et al., 2004). No Brasil, estudo transversal com 22 famílias e outro longitudinal, com 16 pares de mães e filhos, confirmaram que a AP-PCR é um método altamente eficiente para diferenciar clones de S.mutans nas famílias (SPOLIDORIO et al., 2003), bem como para estudar a transmissão vertical, diversidade genotípica e a estabilidade dos genótipos em crianças de creche, acompanhadas por 20 meses, e suas mães (KLEIN et al., 2004).

Independentemente do método, as pesquisas apontaram as mães como principal fonte de infecção por EM para os filhos, levando alguns autores a sugerir que o atraso da infecção inicial delas originadas seria importante para a prevenção da cárie nas crianças (ALALUUSUA, RENKONEN, 1983; KOHLER et al., 1983). No entanto, quando se pesquisa a porcentagem de pares de mães e filhos que compartilham genótipos observa-se grande variação entre os autores, encontrando-se desde altas porcentagens, em autores como LI, CAUFIELD, 1995; KLEIN et al., 2004 e ERSIN et al., 2004, até baixas porcentagens, conforme EMANUELSSON, LI, BRATTHALL, 1998, e KOZAI et al.,1999 e, em decorrência, conclusões contraditórias. Assim, LI, CAUFIELD (1995), por exemplo, observaram relação entre o desenvolvimento de cárie e a similaridade dos S.mutans de mães e filhos quanto ao gênero e a raça, com maior fidelidade de transmissão de mãe para filha $(88 \%)$ do que de mãe para filho (53\%). Entretanto, os meninos com genótipos idênticos aos maternos tiveram 13 vezes maior probabilidade de desenvolver cárie aos 3 anos do que as meninas. Outros autores, porém, não detectaram influência significante do gênero das crianças sobre a fidelidade de transmissão (LI et al., 2000). Portanto, a abrangência das medidas preventivas pode ir além da intervenção apenas nas mães.

CAUFIELD (1997) observaram que crianças amamentadas no peito adquirem EM com fidelidade significantemente maior que aquelas não amamentadas dessa forma. Discutem que as crianças amamentadas no peito têm uma interação mais intensa com suas mães, favorecendo a transferência das bactérias orais. Mas, que, além disso, o leite materno contém imunoglobulinas que podem desempenhar um papel em orientar quais bactérias indígenas podem colonizar. Junto com os fatores imunológicos transferidos pela placenta, pode ser que esses fatores desempenhem um papel para levar o bebê a selecionar preferencialmente aqueles microrganismos indígenas vindos da mãe, enquanto exclui aqueles vindos do pai e de outras fontes. 
Embora a homologia dos genótipos de S.mutans seja mais comum entre mães e filhos, os pais e indivíduos estranhos à família podem ser fonte importante de transmissão (EMANUELSSON, THORNQUIST, 2001), mas não existe um modelo válido para todas as famílias ou populações. Há relatos tanto de isolados semelhantes entre pais e filhos na China (REDMO EMANUELSSON, WANG, 1998), no Japão (KOZAl et al.,1999; TEDJOSASONGKO, KOZAI, 2002) e Brasil (SPOLIDORIO et al., 2003), como ausência de transmissão pai-filho, nos Estados Unidos (LI, CAUFIELD, 1995) e Suécia (EMANUELSSON, LI, BRATTHALL, 1998); transmissão entre esposos no Canadá (KULKARNI et al., 1989), na China (REDMO EMANUELSSON, WANG, 1998), na Finlândia (SAARELA et al., 1993) e Turquia (ERSIN et al., 2004), ou compartilhamento pai-mãe-filho na China (REDMO EMANUELSSON, WANG, 1998), no Brasil (SPOLIDORIO et al., 2003) e na Turquia (ERSIN et al., 2004). A existência de genótipos não encontrados na família já foi relatada por alguns (KULKARNI et al., 1989; KOZAl et al., 1999; TEDJOSASONGKO, KOZAI, 2002; LINDQUIST, EMILSON, 2004;). Há ainda relatos de cepas idênticas de S.mutans em crianças de creches (MATTOS GRANER et al.,2001; TEDJOSASONGKO, KOZAI, 2002; LIU et al., 2007), não encontradas por outros (KLEIN et al., 2004).

Quanto ao número de genótipos, crianças na faixa de 0-3 anos exibem de 1 a 5 genótipos distintos de EM (CAUFIELD, WALKER, 1989; EMANUELSSON, LI, BRATTHALL, 1998; GRONROOS et al., 1998; KOZAl et al., 1999; MATTOS GRANER et al.,2001; SPOLIDORIO et al., 2003; KLEIN et al., 2004), enquanto o número de genótipos abrigados pelas mães pode ser igual (REDMO EMANUELSSON, WANG, 1998) ou maior (LI, CAUFIELD, 1995; ALALUUSUA et al., 1996; EMANUELSSON, LI, BRATTHALL, 1998; LINDQUIST, EMILSON, 2004) que o encontrado nos filhos. Em geral, os isolados pesquisados provêm da saliva, mas a colonização pode ser sítio-específica . Quando da amostragem de vários sítios (saliva sublingual, dorso da língua, mucosa dos rebordos maxilares e mandibulares e biofilme, quando havia dentes) em crianças, tanto o número de isolados (saliva 194 e biofilme - 272), como o número de genótipos de S.mutans detectados (saliva - 29 e biofilme - 35) foi maior na placa (KLEIN et al., 2004). Numa comparação do total de genótipos detectados na saliva, biofilme de esmalte sem cárie e de lesão cariosa, feita por GRONRÖOS, ALALUUSUA (2000), 80\% apareceram na saliva. LEMBO (2005) detectou porcentagem ainda menor (62,7\%). Significa dizer que a 
amostragem de saliva é bem eficiente para o isolamento de cepas de EM mas necessariamente não revela todos os genótipos. Ao se fazer análise qualitativa, é necessário amostrar múltiplos sítios da dentição (GRONROOS; ALALUUSUA, 2000). Os adultos geralmente são colonizados por múltiplos genótipos, havendo estabilidade da colonização por longo tempo (CAUFIELD, WALKER, 1989; GRONROOS et al., 1995, 1998; EMANUELSSON, THORNQUIST, 2000; REDMO EMANUELSSON et al. 2003; NAPIMOGA et al., 2004).

A estabilidade da infecção por S.mutans já foi demonstrada por até 25 anos (LI, CAUFIELD, 1995). No entanto, as mesmas flutuações, que ocorrem nos níveis salivares de EM, são observadas no número de genótipos encontrados ao longo do tempo em crianças (ALALUUSUA et al., 1994; REDMO EMANUELSSON et al. 2003) e em crianças e seus pais (CAUFIELD, WALKER, 1989; KULKARNI et al., 1989). Em relação à aquisição inicial, a estabilidade que se detecta na colonização de EM não é tão verdadeira quando se estudam os genótipos: 6 de 15 genótipos inicialmente detectados em 10 crianças suecas permaneceram, os outros 9 desapareceram, significando colonização transitória ou níveis abaixo do nível de detecção (LINDQUIST, EMILSON, 2004). Em 50\% das crianças brasileiras acompanhadas por KLEIN et al. (2004), de 30 genótipos detectados na aquisição inicial e coletas confirmatórias subseqüentes, 19 (63,3\%) foram transitórios e 11 $(36,7 \%)$, estáveis. Oito desses 11 genótipos estáveis foram transmitidos pelas mães. O estudo demonstrou aumento na diversidade genotípica de S.mutans com o passar do tempo, persistência dos genótipos adquiridos inicialmente, normalmente os transmitidos pela mãe, perda de alguns, e aquisição de novos genótipos.

$\mathrm{Na}$ Suécia, EMANUELSSON, LI, BRATTHALL, (1998) encontraram grande diversidade genotípica em $18 \%$ das crianças que, individualmente, apresentaram de 1 a 3 genótipos de S.mutans. A reavaliação do mesmo grupo de 11 famílias, feita com um intervalo de 2 a 3 anos (EMANUELSSON, THORNQUIST, 2000), com a idade das crianças variando dos 5 aos 8 anos, demonstrou que 9 das 11 crianças apresentaram de 1 a 2 genótipos semelhantes, e que as duas crianças restantes perderam os genótipos do estudo anterior e ganharam dois novos. Os 21 adultos mantiveram de um a dois genótipos idênticos encontrados na primeira vez. Entretanto, nove deles perderam um genótipo, e 8 ganharam de 1 a 2 novos genótipos. Em 2001, o reexame de 13 crianças não-colonizadas no estudo de 1998 mostrou que 10 permaneceram negativas para S.mutans. Das 3 crianças restantes 
positivas para S.mutans, uma apresentou genótipo semelhante ao da mãe, outra apresentou genótipo semelhante ao do pai e a terceira criança apresentou genótipos diferentes de seus pais. Nenhum dos pais compartilhou genótipos idênticos entre si, mas todos os seis adultos mantiveram pelo menos 1 genótipo da primeira visita (REDMO EMANUELSSON, THORNQUIST, 2001). 
3. Proposição 


\section{PROPOSIÇÃO}

Membros de 14 famílias brasileiras de baixa renda, com primogênitos de 7 meses de idade no início, tiveram amostras de saliva coletadas e cultivadas longitudinalmente até os 30 meses de vida da criança, para isolamento de estreptococos mutans, com vistas a verificar:

1 - a transmissibilidade dos S. mutans dos adultos para as crianças;

2 - a similaridade dos genótipos entre membros da mesma família;

3 - a estabilidade e variação dos genótipos ao longo do tempo. 
4. Material e Métodos 


\section{MATERIAL E MÉTODOS}

\subsection{População}

A população em estudo derivou-se de um grupo maior de mães e filhos do projeto "Prevenção da transmissão de estreptococos mutans de mães para filhos" realizado na Faculdade de Odontologia de Bauru - USP em conjunto com a Universidade de Pittsburgh, aprovado pelos Comitês de Ética das duas Universidades e pelo Conselho Nacional de Ética do Ministério da Saúde (Anexo 1).

Os critérios utilizados para inclusão das mães no projeto foram: ser primíparas; apresentar níveis altos $\left(\geq 10^{6} \mathrm{UFC} / \mathrm{ml}\right)$ de estreptococcus mutans $(E M / m l)$, pelo teste simplificado Strip mutans ${ }^{\circledR}$ (Orion Diagnostica, Helsinki, Finlândia), quando a criança tinha dois meses e meio de vida; mais de 20 dentes presentes e ausência de doença sistêmica ou ingestão de medicamentos. No caso da sub-amostra (NOCE, 2005), a residência do pai na mesma casa, foi um critério adicional e o início do estudo coincidiu com os 7 meses da criança. A presença de outro adulto na casa não foi um critério para participar mas se presente uma agregada (tia ou avó), esta era convidada a entrar. Somente as mães, por fazerem parte do grupo controle do projeto, receberam tratamento odontológico desde a seleção.

Participaram do estudo 14 famílias, classificadas pela renda como de baixo nível sócio-econômico (GRACIANO, LEHFELD, NEVES FILHO, 1996), residentes em áreas de concentrações sub-ótimas de flúor (0,60 a 0,79 mg F/L) em Bauru.

A média de idade dos adultos foi $20,9 \pm 4,9$ anos, para as mães; $23,6 \pm 3,4$ anos, para os pais e $41,6 \pm 11,5$ anos para as agregadas. Todos os participantes receberam informação detalhada sobre o estudo (Anexo 2), assinando um Termo de Consentimento Livre e Esclarecido (Anexo 2). 


\subsection{Exame clínico e Questionário}

Para definir a prevalência e a atividade de cárie nos adultos, foi determinado o índice CPOS, segundo os critérios da OMS, através de exames clínico e radiográfico na visita 1 (V1), ocorrida aos 7 meses de vida da criança, repetindo-se o exame clínico 4-5 meses depois (V2). Nessas mesmas visitas foram determinados os níveis de EM na saliva, para estabelecer a intensidade da infecção, e isolamento de colônias de EM, para estabelecer as vias de transmissão adultocriança, e não o inverso, quando a criança fosse colonizada. Com vistas a determinar a estabilidade de infecção dos isolados, foi feita nova colheita de saliva ao final do estudo (V4), somente das mães. Ainda na visita 1, foi avaliado o índice de sangramento papilar (LOESCHE, 1979) de boca toda, posteriormente adaptado ao índice gengival (IG) de LOE (1967); aplicado questionário simplificado sobre saúde e levantadas as condições sócio-econômicas e escolaridade dos pais. Em todas as visitas foram investigados o uso de antibióticos nos últimos 3 meses, hábitos de risco para transmissão de EM e hábitos de higiene bucal e dieta dos bebês.

As crianças foram examinadas quanto ao número de dentes e cárie dental, pelo índice ceos, e os níveis salivares de EM em saliva não-estimulada em 4 visitas, quando contavam com 7-8 meses (V1), 11-12 meses (V2), 17-19 meses (V3) e 29-30 meses (V4).

\subsection{Exame bacteriológico e isolamento de EM da saliva}

As amostras de saliva dos adultos foram obtidas após mastigação de goma de parafina e mantidas em gelo até o processamento, dentro de 30-60 minutos. As amostras dos bebês foram colhidas do assoalho da boca, à medida que a saliva se formava, com uma cânula fina acoplada a uma seringa estéril, transferida para tubos eppendorf estéreis e mantida em gelo até o processamento. Após homogeneização durante 60 segundos em agitador "vortex" (Leucotron ${ }^{\circledR}$, Sta.Rita do Sapucaí, MG, Brasil), e diluição seriada em tampão fosfato de potássio $0,05 \mathrm{M}, \mathrm{pH}$ 
7,1, alíquotas de $50 \mu \mathrm{l}$ foram semeadas com bastões de vidro em $\mathrm{L}$ em placas de agar SB-20, seletivo para EM, contendo $20 \%$ de sacarose e $0,2 \mathrm{U} / \mathrm{ml}$ de bacitracina (DAVEY; ROGERS, 1984), e incubadas em jarras de anaerobiose (Difco, Detroit, MI, USA), por 48 horas a $37^{\circ}$.C. Com o emprego de microscópio estereoscópico (Wild, Heerbrurgg, Suíça) as contagens de unidades formadoras de colônias (UFC) foram feitas baseado na morfologia típica de EM (DAVEY E ROGERS, 1984 e AZEVEDO, ZELANTE, 1994). A seguir, até 20 colônias representativas de EM de cada placa foram passadas para caldo $\mathrm{BHI}$ (Difco) e incubadas por 24 horas a $37^{\circ}$.C. Uma vez observada a pureza da cultura, $500 \mu \mathrm{l}$ foram adicionados a $500 \mu \mathrm{l}$ de caldo BHI com $20 \%$ de glicerol e feita a estocagem à $-86^{\circ}$.C, para posterior identificação definitiva e genotipagem.

\subsection{Identificação dos estreptococos mutans}

Os estudos de identificação e similaridade dos EM foram executados na Universidade de Pittsburgh (PA, EUA) e no Instituto Forsyth (Boston, MA, EUA) sob a co-orientação do Prof. Dr. Walter A. Bretz e assessoria da Dra. Anne Tanner.

Inicialmente, as amostras foram descongeladas, homogeneizadas no vortex por 60 segundos e alíquotas de $10 \mu \mathrm{l}$ foram inoculadas em placas de ágar sangue e incubadas por 48 horas em câmara de anaerobiose (Anexo 3) (Innovative Technology Inc., Newburyport, MA, EUA) a $37^{\circ}$ C. Observadas a morfologia e pureza, os isolados removidos de meia placa de ágar sangue foram conservados em $100 \mu \mathrm{l}$ de solução TE (50 mM Tris HCl, 1 mM EDTA, pH 7.6) e mantidos a - $20^{\circ} \mathrm{C}$ até sua identificação pelo método de hibridização DNA-DNA checkerboard (SOCRANSKY et al,2004) e genotipagem por reação em cadeia da polimerase com iniciadores arbitrários (AP-PCR).

Hibridização DNA-DNA checkerboard. Alíquotas de $20 \mu \mathrm{l}$ da suspensão descongelada dos isolados foram adicionadas a tubos eppendorf contendo $55 \mu \mathrm{l}$ de TE (10 mM Tris $\mathrm{HCl}, 1 \mathrm{mM}$ EDTA, $\mathrm{pH}$ 7.6). A seguir, foram adicionados mais $50 \mu \mathrm{l} \mathrm{NaOH}$ a $0,5 \mathrm{M}$, as suspensões foram fervidas em banho- 
maria por 10 minutos e neutralizadas pela adição de $400 \mu \mathrm{l}$ de acetato de amônia a 5M filtrado. O DNA liberado foi depositado em uma das canaletas do Minislot 90 (Immunetics, Cambridge, MA, EUA) (Anexo 3), e depois concentrado em uma membrana de nylon (15 x 15cm) com carga positiva (Roche, Indianápolis, IN, EUA). O Minislot 90 permite a deposição de 84 amostras diferentes em canaletas individuais, e de 6 canaletas para os controles representados por um "pool" de bactérias, com $10^{5}$ e $10^{6} \mathrm{UFC} / \mathrm{ml}$, dentre as quais encontram-se 10 espécies de bactérias Gram positivas - Actinomyces israelii, Actinomyces naes/undii, Streptococcus gordonii, Streptococcus mitis, Streptococcus sanguinis, Streptococcus oralis, Streptococcus mutans (2) e Streptococcus sobrinus (2).

Após remoção da membrana do Minislot 90, o DNA foi fixado à mesma por luz ultravioleta (Stralinker® 1800, Stratagene, La Jolla, CA, EUA), seguido da secagem da membrana a $80^{\circ} \mathrm{C}$ por 10 minutos e sua armazenagem a $4^{\circ} \mathrm{C}$ até os processos de pré-hibridização e hibridização.

As membranas foram pré-hibridizadas a $42^{\circ} \mathrm{C}$ por 1 hora, em uma solução contendo $50 \%$ formamida, 2 x SSC (standard saline citrate - 1 x SSC = $150 \mathrm{mM} \mathrm{NaCl}, 15 \mathrm{mM}$ de citrato de sódio, pH 7,0), 1\% de caseína (Sigma Chemical Co., St. Louis, MO, USA), 5x de reagente de Denhardt's (Fischer Scientific, Pittsburgh, PA, EUA), 25 mM de fosfato de sódio ( $\mathrm{pH} \mathrm{6,5)} \mathrm{e} \mathrm{0,5} \mathrm{mg/ml} \mathrm{de} \mathrm{RNA} \mathrm{de}$ levedura (Boehringer Mannheim, Indianápolis, IN, EUA).

As sondas de DNA genômico total para as espécies acima citadas foram preparadas pela marcação de $1 \mathrm{ng}$ e $10 \mathrm{ng}$ de DNA de cada espécie com digoxigenina (Random primer digoxigenin labeling kit, Boehringer Manheim, Indianapolis, IN, USA), de acordo com FEINBERG E VOGELSTEIN (1983). As sondas foram desnaturadas a $100^{\circ} \mathrm{C}$ por 5 minutos em cada tampão de hibridização que continha a sonda, e mantidas no gelo.

Para a hibridização, a membrana foi posicionada no Miniblotter (Immunetics) (Anexo 3) de forma que as linhas de DNA ficassem perpendiculares aos canais de hibridização. Em cada canal, foi adicionada uma sonda de DNA (20ng/ml) em $160 \mu \mathrm{l}$ da solução de hibridização composta de $45 \%$ de formamida, 5 X SSC, 1 X de reagente de Denhardt's, $20 \mathrm{mM}$ de fosfato de sódio ( $\mathrm{pH} \mathrm{6,5),} \mathrm{0,2} \mathrm{mg/ml}$ de RNA de levedura (Boehringer Mannheim), 10\% de sulfato de dextrano e 1\% de caseína (Sigma). A hibridização ocorreu por uma noite a $42^{\circ}$.C. 
Após a hibridização, as membranas foram removidas do Miniblotter e lavadas duas vezes (25 minutos cada uma) no aparelho Disk Wisk (Schleicher e Schuell, Keene, NH, USA) (Anexo 3) a $68^{\circ} \mathrm{C}$ em solução tampão composta de $1 \%$ de SDS, $1 \mathrm{mM}$ de EDTA e $20 \mathrm{mM}$ de $\mathrm{Na}_{2} \mathrm{HPO}_{4}$, a fim de remover as sondas que não foram hibridizadas completamente.

Para a detecção dos híbridos, as membranas foram bloqueadas por imersão durante 1 hora numa solução contendo $1 \%$ de ácido maléico, $3 \mathrm{M}$ de $\mathrm{NaCl}$, $0,2 \mathrm{M}$ de $\mathrm{NaOH}, 0,3 \%$ de Tween $20,0,5 \%$ de caseína, $\mathrm{pH} 8,0$, sob agitação. A seguir, as membranas foram incubadas numa solução com anticorpos antidigoxigenina conjugados a fosfatase alcalina diluída a 1:10.000 por 30 minutos em agitador.

As membranas foram depois lavadas 4 vezes, por 10 minutos, em solução de $0,1 \mathrm{M}$ de ácido maleico, $3 \mathrm{M}$ de $\mathrm{NaCl}, 0,2 \mathrm{M}$ de $\mathrm{NaOH}, 0,3 \%$ de Tween 20, pH 8,0, e 1 vez, por 5 minutos, em uma solução de $0,1 \mathrm{M}$ de Tris $\mathrm{HCl}, 0,1 \mathrm{M}$ de $\mathrm{NaCl}, 50 \mathrm{mM}$ de $\mathrm{MgCl}$, $\mathrm{pH}$ 9,5.

Para que os híbridos fossem visualizados, as membranas foram transferidas para uma película plástica e incubadas a noite toda em temperatura ambiente em uma solução reveladora à base de fosfato e uma substância quimioluminescente (Gene Images ${ }^{\mathrm{TM}}$ ECF $^{\mathrm{TM}}$ Detection Kit - GE Healthcare UK Ltd, Buckinghamshire, England, UK) sendo feita a sua leitura através do escâner de fluorescência (Molecular Dynamics Inc, Sunnyvale, CA, EUA) (Anexo 3).

\subsection{Genotipagem dos Streptococcus mutans por AP-PCR}

Extração do DNA. Para os isolados identificados como S.mutans, o protocolo de extração de DNA, para a AP-PCR, foi adaptado do manual de extração do DNeasy Tissue Kit (Anexo 3)(QIAGEN, Valencia, CA, EUA).

Os isolados mantidos em $100 \mu \mathrm{l}$ de solução TE foram descongelados, centrifugados por 10 minutos, a 10.000 x g e o sobrenadante descartado. Ao sedimento foram adicionados $160 \mu \mathrm{l}$ de solução tampão enzimático (20 mM Tris- $\mathrm{HCl}$, 
$\mathrm{pH}$ 8.0; 2 mM EDTA; 1.2\% Triton $\left.^{\circledR} \mathrm{X}-100\right), 20 \mu \mathrm{lde}$ lisozima (180 mg/ml, Difco) e 20 $\mu l$ de acromopeptidase $(2.500 \mathrm{U} / \mathrm{ml}$, Difco) seguidos de incubação em banho-maria por 1 hora a $37^{\circ} \mathrm{C}$.

A seguir, foram adicionados ao tubo $25 \mu \mathrm{l}$ de Proteinase $\mathrm{K}$ e $200 \mu \mathrm{l}$ de solução tampão $\mathrm{AL}$, ambas fornecidas pelo kit, e incubação por uma noite a $55^{\circ} \mathrm{C}$. Após essa incubação, foram adicionados à suspensão $200 \mu \mathrm{l}$ de etanol (96\%), com agitação delicada até a mistura ficar homogênea. Nesta fase observava-se a precipitação do DNA na solução. Toda a mistura foi então transferida para uma coluna (DNeasy spin column), com um filtro (DNeasy membrane) e um orifício (Anexo 3), encaixada em um tubo coletor, e centrifugada a 10.000 x g por 1 minuto, com descarte do tubo coletor. A coluna foi então adaptada a um novo tubo coletor, adicionada de $500 \mu$ da solução AW1 (kit) e centrifugada a 9.000 x g por 1 minuto. Após o descarte, novo tubo coletor foi recolocado, no qual foram adicionados $500 \mu \mathrm{l}$ de solução AW2 (kit) e feita a centrifugação a 14.000 x g por 3 minutos. Descartado o último tubo coletor, a coluna foi colocada num novo tubo eppendorf de $1.5 \mathrm{ml} \mathrm{e}$, sobre o filtro, colocados $100 \mu$ de solução AE para extração do DNA preso ao mesmo. Após um período de incubação de 1 minuto a temperatura ambiente, foi feita a centrifugação a 10.000 x g por 1 minuto e a eliminação da coluna, com a amostra de DNA sendo então mantida no eppendorf em freezer a $-20^{\circ}$.C.

A concentração de DNA de cada amostra foi determinada em espectrofotômetro (NanoDrop® ND-1000, Atkinson, NH, USA).

Genotipagem por AP-PCR. A amplificação por AP-PCR foi feita num volume de $50 \mu \mathrm{l}$ de reação de PCR contendo $25 \mu \mathrm{l}$ de solução para PCR Choice ${ }^{\mathrm{TM}}$ Taq Mastermix DNA polymerase (Denville Scientific Inc. Metuchen, NJ, USA), com 2,5U de Taq DNA Polymerase, 20 mM Tric- $\mathrm{HCl}(\mathrm{pH} 9,0), 3,0 \mathrm{mM} \mathrm{MgCl}, 20 \mathrm{mMKCl}$, $16 \mathrm{mM}\left(\mathrm{NH}_{4}\right) \mathrm{SO}_{4}, 0,1 \%$ Triton X-100, dNTP mix (1,5mM $\left.\mathrm{MgCl}_{2}\right) ; 0,4 \mathrm{mM}$ de primer OPA-02 (oligonucleotídeo 5' - TGCCGAGCTG - 3' - Invitrogen Co. Carlsbad, CA, USA); $2 \mu \mathrm{l}$ de amostra de DNA (média de $170 \mathrm{ng} / \mu \mathrm{l}$ ) e $22 \mu \mathrm{l}$ de água destilada UltraPure DNAase/RNAase-free (Invitrogen).

A amplificação do AP-PCR no termociclador (PTC 200 Thermal Cycler, GMI Ramsey, Minnesota, EUA) (Anexo 3) seguiu o protocolo de Saarela et al. 
(1996), com 35 ciclos nas temperaturas de $94^{\circ} \mathrm{C}$ durante 1 minuto; $36^{\circ}$ por 2 minutos e $72^{\circ} \mathrm{C}$ durante 2 minutos . A desnaturação inicial foi feita a $94^{\circ}$.C por 5 minutos, e a extensão final a $72^{\circ}$.C por 5 minutos (Figura 1). Um controle negativo sem amostra de DNA foi incluído a cada reação de AP-PCR. Os controles positivos foram representados por 3 amostras de S.mutans de membros de famílias diferentes e uma amostra de S.sobrinus.

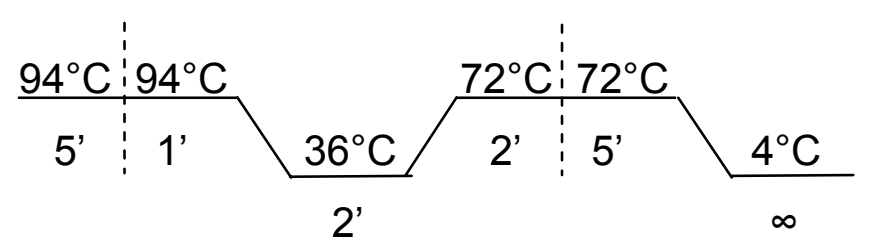

Figura 1 - Ciclos do termociclador, programado segundo SAARELA et al 1996

Os produtos amplificados foram analisados por eletroforose (Model B2 EasyCast ${ }^{\mathrm{TM}}$ Mini Gel Electrophoresis System, Thermo Fisher Scientific, Portsmouth, $\mathrm{NH}$ ) (Anexo 3) em agarose gel (Seakem ${ }^{\circledR}$ LE Agarose, Cambrex Bio Science Rockland, Inc, Rockland, ME, EUA) a 1,2\% em tampão $5 \times$ TBE (Tris-Borato-EDTA) em corrida a 70V (Power Pac 3000, RIO-RAD, Hercules, CA, USA) (Anexo 3) por duas horas e trinta minutos em tampão $0.5 \times$ TBE. Um marcador padrão de peso molecular de $1 \mathrm{kbp}$ (250 a 10.000 pares de base - Promega Co., Madison, WI, EUA) foi adicionado a cada gel. Após a corrida, o gel foi corado com brometo de etídio a 0,25\% (Sigma-Aldrich Co, St. Louis, MO, EUA), visualizado, fotografado por luz ultravioleta (Multimage Light Cabinet, Alpha Innotech Co., San Leandro, CA, EUA) (Anexo 3) e suas imagens salvadas no formato TIFF.

Os padrões de banda gerados no gel de cada isolado da mesma família foram analisados lado a lado, visualmente, e uma matriz de 0 e 1 foi construída baseada na ausência (0) e presença (1) das bandas marcadas. Os padrões dos genótipos foram considerados similares quando a maioria das bandas era idêntica em alcance entre 250 e 1500 bp. 


\subsection{Análise Estatística}

As variáveis do Índice gengival, o índice CPO-S e o nível de EM na saliva dos adultos foram comparados através do teste de Mann Whitney. As variáveis EM na saliva e hábitos de risco dos adultos, o tempo de amamentação, e a renda familiar foram comparadas com a presença e ausência de cárie na criança pelo teste de Mann Whitney. A relação entre a presença de cárie nas crianças e o tipo de parto (normal ou cesariana) ou a presença de açúcar em sua dieta foi pesquisada pelo teste exato de Fisher, e, com a raça, pelo teste Qui-quadrado.

Foi utilizado o teste de Spearman determinar a correlação entre o tempo de aquisição inicial dos EM na saliva nas crianças e o número de dentes e nível de EM na saliva nas quatro visitas. $O$ valor de $p \leq 0,05$ foi considerado estatisticamente significante. 
5. Resultados 


\section{RESULTADOS}

\subsection{Dados clínicos e quantificações de EM}

$\mathrm{Na}$ tabela 1 estão representados a idade, número de dentes e os valores médios dos índices CPOS e gengival (IG), bem como os escores médios de EM quantificados nas salivas dos adultos das 14 famílias nas visitas 1 e 2, enquanto na tabela 2, as médias e desvios-padrão desses indicadores. Feita a comparação dos indicadores clínicos entre mães, pais e agregadas pelo teste de Mann Whitney, não se observou diferença significante entre mães e pais para o índice CPO-S $(p=0,285)$. Todavia, a comparação de ambos com as agregadas resultou significante para as mães $(p=0,010)$ e os pais $(p=0,002)$, face ao alto número de extrações nas agregadas. Não se observou diferença estatisticamente significante entre mães, pais e agregadas para o IG $(p>0,05)$.

O escore médio de EM na saliva das mães foi bem mais elevado que $o$ dos pais e agregadas, pelo teste de Mann Whitney, resultando em $p=0,027$ na comparação entre os primeiros, e $p=0,008$ entre mães e agregadas. Não houve diferença quando comparados os escores de EM na saliva dos pais e agregadas $(p=0,238)$. 
50 Resultados

Tabela 1 - Características clínicas e escores de EM das 14 Famílias

\begin{tabular}{|c|c|c|c|c|c|c|}
\hline Família & & Idade & $n^{\circ}$ dentes & IG & CPO-S & $\mathrm{EM}^{\star}$ \\
\hline \multirow[t]{3}{*}{1} & Mãe & 16 & 25 & 0,85 & 22 & 4 \\
\hline & Pai & 23 & 30 & 1,52 & 21 & 2 \\
\hline & Avó & 43 & 15 & 1,09 & 87 & 2 \\
\hline \multirow[t]{3}{*}{$2^{\#}$} & Mãe & 18 & 28 & 1,31 & 12 & 4 \\
\hline & Pai & 25 & 26 & 0,64 & 24 & 2 \\
\hline & Avó & 49 & 24 & 0,35 & 47 & 1 \\
\hline \multirow[t]{2}{*}{3} & Mãe & 19 & 27 & 1,25 & 33 & 3 \\
\hline & Pai & 20 & 25 & 0,70 & 23 & 2 \\
\hline \multirow[t]{3}{*}{$4^{\#}$} & Mãe & 23 & 28 & 1,61 & 20 & 4 \\
\hline & Pai & 24 & 30 & 1,15 & 34 & 2 \\
\hline & Avó & 51 & 22 & 1,00 & 59 & 1 \\
\hline \multirow[t]{2}{*}{$5^{\#}$} & Mãe & 21 & 28 & 0,61 & 24 & 4 \\
\hline & Pai & 20 & 31 & 1,68 & 19 & 3 \\
\hline \multirow[t]{3}{*}{6} & Mãe & 25 & 31 & 1,03 & 13 & 2 \\
\hline & Pai & 22 & 32 & 1,43 & 15 & 2 \\
\hline & Avó & 44 & 31 & 1,32 & 24 & 1 \\
\hline \multirow[t]{2}{*}{7} & Mãe & 19 & 27 & 0,96 & 24 & 3 \\
\hline & Pai & 20 & 28 & 1,00 & 5 & 2 \\
\hline \multirow[t]{2}{*}{8} & Mãe & 18 & 28 & 1,42 & 9 & 1 \\
\hline & Pai & 25 & 30 & 1,33 & 17 & 1 \\
\hline \multirow[t]{2}{*}{9} & Mãe & 19 & 26 & 1,27 & 46 & 1 \\
\hline & Pai & 24 & 31 & 1,14 & 8 & 2 \\
\hline \multirow[t]{3}{*}{10} & Mãe & 17 & 27 & 0,58 & 9 & 2 \\
\hline & Pai & 18 & 29 & 1,08 & 8 & 1 \\
\hline & Avó & 36 & 18 & 0,86 & 62 & 2 \\
\hline \multirow[t]{3}{*}{11} & Mãe & 35 & 30 & 0,93 & 47 & 2 \\
\hline & Pai & 26 & 28 & 1,00 & 1 & 0 \\
\hline & Tia & 16 & 28 & 1,27 & 10 & 2 \\
\hline \multirow[t]{2}{*}{12} & Mãe & 23 & 25 & 1,25 & 42 & 4 \\
\hline & Pai & 31 & 30 & 1,53 & 20 & 4 \\
\hline \multirow[t]{3}{*}{13} & Mãe & 23 & 27 & 1,50 & 51 & 4 \\
\hline & Pai & 27 & 27 & 1,17 & 43 & 2 \\
\hline & Avó & 51 & 10 & 1,12 & 92 & 1 \\
\hline \multirow[t]{3}{*}{14} & Mãe & 17 & 28 & 1,77 & 14 & 4 \\
\hline & Pai & 25 & 26 & 1,05 & 39 & 2 \\
\hline & Avó & 43 & 0 & & 128 & 2 \\
\hline
\end{tabular}


Tabela 2 - Médias e desvios-padrão das características clínicas e escores de EM dos adultos das 14 famílias

\begin{tabular}{llllll}
\hline Integrante & Idade & $\mathbf{n}^{\circ}$ dentes & IG & CPOS & EM \\
\hline \multirow{2}{*}{ Mãe } & 20,93 & 27,50 & 1,17 & 25,50 & 3,00 \\
& $\pm 4,89$ & $\pm 1,65$ & $\pm 0,30$ & $\pm 14,96$ & $\pm 1,17$ \\
& & & & & \\
Pai & 23,57 & 28,78 & 1,17 & 19,57 & 1,92 \\
& $\pm 3,41$ & $\pm 2,15$ & $\pm 0,30$ & $\pm 12,24$ & $\pm 0,91$ \\
\multirow{2}{*}{ Agregada } & 41,62 & 18,50 & 1,00 & 63,37 & 1,50 \\
& $\pm 11,51$ & $\pm 10,11$ & $\pm 0,33$ & $\pm 38,40$ & $\pm 0,53$ \\
\hline
\end{tabular}

A Tabela 3 apresenta o número de dentes irrompidos, índice ceos e escores de EM na saliva das crianças nas quatro visitas. Uma criança não compareceu na visita 4 (\# 7). Na V4, todas as crianças apresentavam dentição completa sendo que apenas três desenvolveram cárie, uma do gênero masculino (\# 4) e duas do gênero feminino (\# 2 e 5). Além dessas, outras sete apresentaram EM, restando apenas três crianças (\# 3, 6 e 13) sem EM na última visita. 
52 Resultados

Tabela 3 - Número de dentes irrompidos, ceos e escores de EM nas 14 crianças

\begin{tabular}{|c|c|c|c|c|c|c|c|c|c|}
\hline \multirow{2}{*}{$\begin{array}{l}\text { Criança } \\
\text { (Gênero) }\end{array}$} & \multicolumn{4}{|c|}{$n^{\circ}$ dentes } & \multirow{2}{*}{$\begin{array}{c}\text { ceos } \\
\text { V4 }\end{array}$} & \multicolumn{4}{|c|}{ Escores de EM/ml } \\
\hline & V1 & V2 & V3 & V4 & & V1 & V2 & V3 & V4 \\
\hline $1(\mathrm{~F})$ & $\overline{0}$ & $\overline{4}$ & 7 & 20 & 0 & 0 & 0 & 4 & 1 \\
\hline $2^{\ominus}(F)$ & 0 & 4 & 10 & 20 & 4 & 0 & 1 & 4 & 2 \\
\hline $3(\mathrm{M})$ & 0 & 5 & 10 & 20 & 0 & 0 & 0 & 0 & 0 \\
\hline $4^{\vartheta}(\mathrm{M})$ & 0 & 5 & 12 & 20 & 1 & 1 & 0 & 4 & 2 \\
\hline $5^{\diamond}(\mathrm{F})$ & 0 & 8 & 13 & 20 & 4 & 0 & 0 & 0 & 3 \\
\hline $6(F)$ & 0 & 8 & 12 & 20 & 0 & 0 & 0 & 0 & 0 \\
\hline $7(F)$ & 0 & 2 & 7 & * & * & 0 & 1 & 0 & * \\
\hline $8(\mathrm{M})$ & 0 & 6 & 12 & 20 & 0 & 0 & 0 & 0 & 2 \\
\hline $9(\mathrm{M})$ & 0 & 6 & 11 & 20 & 0 & 0 & 0 & 0 & 1 \\
\hline $10(\mathrm{M})$ & 0 & 4 & 6 & 20 & 0 & 0 & 0 & 0 & 1 \\
\hline $11(F)$ & 0 & 2 & 7 & 20 & 0 & 0 & 0 & 0 & 1 \\
\hline $12(F)$ & 0 & 8 & 12 & 20 & 0 & 0 & 0 & 0 & 1 \\
\hline $13(F)$ & 0 & 5 & 12 & 20 & 0 & 0 & 0 & 0 & 0 \\
\hline $14(F)$ & 0 & 2 & 12 & 20 & 0 & 0 & 0 & 0 & 1 \\
\hline
\end{tabular}

* - Não compareceu à avaliação

$\checkmark$ - Crianças com cárie

O teste de Spearman não mostrou correlação entre o maior ou menor número de dentes e o momento de detecção inicial dos EM nas crianças (Tabela 4).

Tabela 4 - Correlação entre o número de dentes e o momento de detecção (MD) inicial de EM pelo teste de Spearman*

\begin{tabular}{|c|c|c|c|}
\hline & $\mathbf{n}$ & $r$ & $p$ \\
\hline $\mathrm{n}^{\circ}$ dentes V2 $\times$ MD & 14 & 0,253 & $0,382 \mathrm{~ns}$ \\
\hline$n^{\circ}$ dentes V3 $\times$ MD & 14 & 0,274 & $0,341 \mathrm{~ns}$ \\
\hline
\end{tabular}

${ }^{*}$ Significante: $p<0,05$ 
Com base na ausência ou presença de cárie, as crianças foram divididas em dois grupos que foram, então, comparados relativamente a algumas variáveis já associadas com essa condição. A comparação entre os valores médios de CPOS e EM na saliva das mães e pais das crianças com e sem cárie pelo teste de Mann Whitney não revelou diferença estatisticamente significante $(p>0,05)$ (Tabela 5).

Tabela 5 - Comparação dos índices CPOS e escores de EM dos pais de crianças com e sem cárie pelo teste de Mann Whitney*

\begin{tabular}{|c|c|c|c|c|c|}
\hline \multirow{2}{*}{ Crianças (n) } & & \multicolumn{2}{|c|}{ CPOS } & \multicolumn{2}{|c|}{$\mathrm{EM} / \mathrm{ml}$} \\
\hline & & Mãe & Pai & Mãe & Pai \\
\hline & Média & 18,67 & 25,67 & 4,00 & 2,33 \\
\hline $\begin{array}{c}\text { Com cárie } \\
\text { (3) }\end{array}$ & DP & 6,11 & 7,64 & 0 & 0,57 \\
\hline & Média & 28,00 & 19,20 & 2,70 & 1,80 \\
\hline $\begin{array}{c}\text { Sem cárie } \\
\text { (10) }\end{array}$ & $\mathrm{DP}$ & 17,05 & 12,94 & 1,25 & 1,03 \\
\hline & $p$ & $0,573_{n s}$ & $0,370_{n s}$ & $0,160_{n s}$ & $0,370_{n s}$ \\
\hline
\end{tabular}

*Significante: $p<0,05$ 
Os dois grupos de crianças não diferiram significantemente quanto a variáveis como tempo de amamentação (teste de Mann Whitney), gênero, uso de açúcar ou forma de nascimento - parto normal ou cesariana (teste exato de Fisher) ou raça (teste do Qui-quadrado). No entanto, a comparação dos escores de EM na saliva na última visita mostrou que as crianças com cárie apresentaram maior escore de EM, pelo teste de Mann Whitney $(p=0,013)$. As médias e desvios-padrão dos escores de EM na saliva de crianças com e sem cárie foram, respectivamente, 2,33 $\pm 0,57$ e $0,70 \pm 0,67$.

A tabela 6 indica o número de hábitos de risco: compartilhar colher; assoprar colher; dormir na mesma cama e beijar a criança na boca, dos familiares de crianças dos dois grupos. A comparação entre eles pelo teste de Mann Whitney não revelou diferença estatisticamente significante $(p>0,05)$.

Tabela 6 - Hábitos de risco $(n=4)$ dos adultos das famílias de crianças com e sem cárie

\begin{tabular}{ccccc}
\hline Crianças & Família & Mãe & Pai & Agregada \\
\hline \multirow{3}{*}{ Com cárie } & 2 & $4 / 4$ & $2 / 2$ & $2 / 2$ \\
& 4 & $1 / 4$ & $1 / 4$ & $1 / 4$ \\
Média e DP & 5 & $3 / 4$ & $4 / 4$ & - \\
\cline { 2 - 5 } & & 2,66 & 2,33 & 1,5 \\
& 1 & $\pm 1,52$ & $\pm 1,52$ & $\pm 0,70$ \\
\hline \multirow{4}{*}{ Sem cárie } & 3 & $1 / 4$ & $4 / 4$ & $3 / 4$ \\
& 6 & 0 & $2 / 4$ & - \\
& 7 & 0 & $3 / 4$ & - \\
& 8 & $3 / 4$ & $3 / 4$ & - \\
& 10 & $2 / 4$ & $1 / 4$ & - \\
& 11 & $4 / 4$ & $3 / 4$ & 0 \\
& 12 & $1 / 4$ & $1 / 4$ & 0 \\
& 13 & $4 / 4$ & $2 / 4$ & - \\
& 14 & $2 / 4$ & $3 / 4$ & 0 \\
\hline$p^{*}$ & & 2,2 & 2,4 & 1,16 \\
& & $\pm 1,31$ & $\pm 0,96$ & $\pm 1,32$ \\
\hline
\end{tabular}

*Significante: $p<0,05$ 


\subsection{Identificação e genotipagem dos estreptococos mutans}

Identificação. Do total de 565 isolados pesquisados, 551 (97,5\%) foram identificados como estreptococos mutans, sendo 506 Streptococcus mutans, 45 Streptococcus sobrinus e 14 não foram identificados. Para a genotipagem foram selecionadas apenas 8 famílias por apresentarem EM em todos os membros, como ilustração, a Figura 2 mostra o resultado da identificação dos EM por hibridização DNA-DNA de algumas crianças.

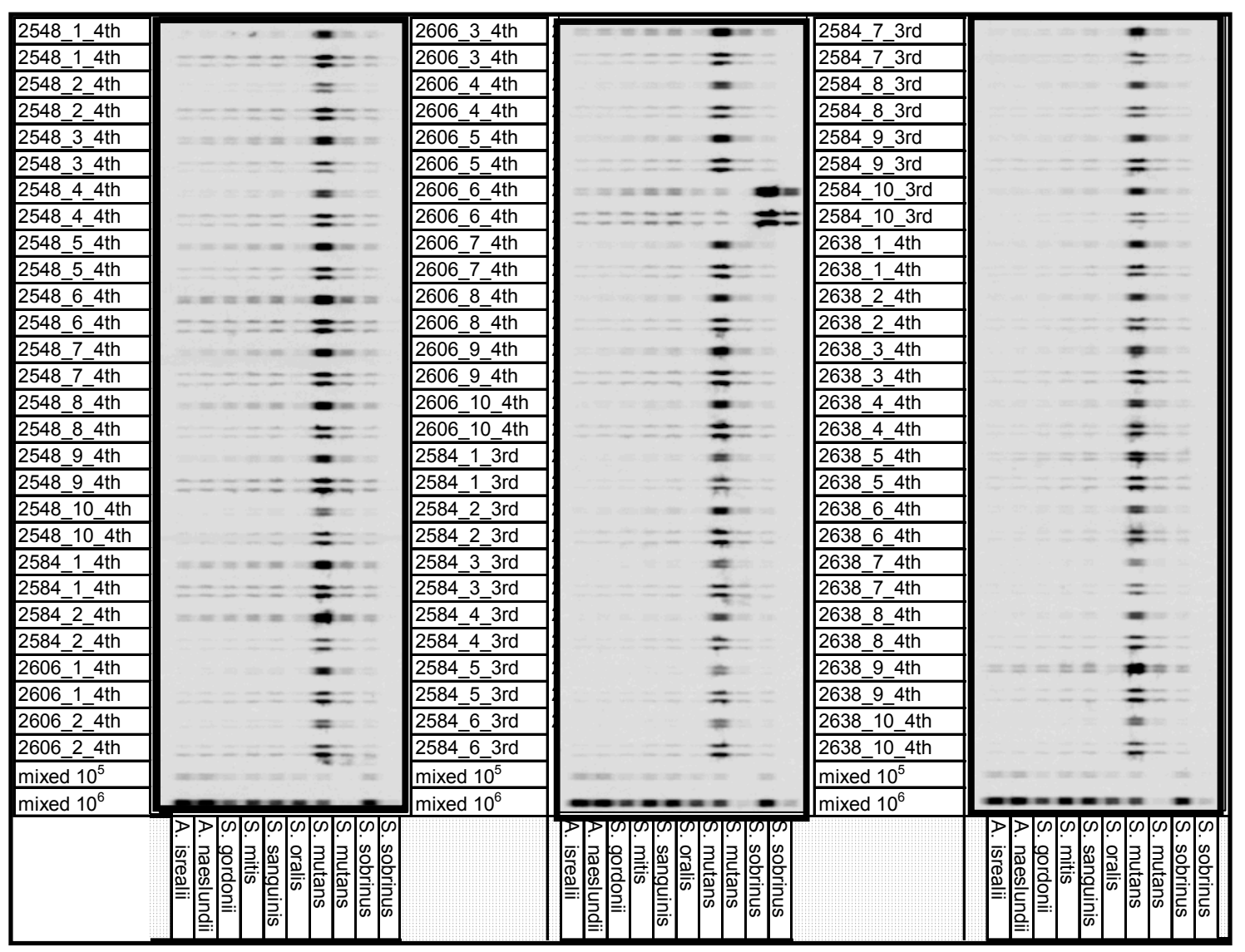

Figura 2 - Exemplo de um Checkerboard usado para detectar 8 espécies bacterianas em isolados de algumas crianças. As linhas verticais contêm as sondas das espécies indicadas abaixo na figura. As linhas horizontais possuem as amostras dos isolados das crianças. As duas últimas linhas horizontais estão os controles padrões $10^{5}$ e $10^{6} \mathrm{UFC} / \mathrm{ml}$. 
Genotipagem. A tabela 7 mostra o total de isolados de S.mutans examinados nas 8 famílias. As reações com o iniciador OPA-02 dos 506 isolados de S.mutans geraram até 15 bandas, com peso variando entre 250 e 2500 pb. (Figura 3). A análise dos géis com os produtos do iniciador OPA-02 foi realizada por comparação visual. O total de genótipos detectados foi 20 , com um máximo de 4 genótipos nos adultos e máximo de 2 nas crianças.

Tabela 7 - Total de isolados de Streptococcus . mutans genotipados nos membros das 8 famílias

\begin{tabular}{llllll}
\hline Família & Mãe & Pai & Agregada & Criança & Total \\
\hline 1 & 23 & 16 & 19 & 20 & 78 \\
2 & 12 & 20 & 19 & 30 & 81 \\
4 & 30 & 19 & 21 & 12 & 82 \\
5 & 28 & 20 & $N T$ & 10 & 58 \\
$7^{* *}$ & 20 & 10 & $N T$ & 10 & 40 \\
8 & 28 & 20 & $N T$ & 10 & 58 \\
10 & 23 & 12 & 24 & 6 & 65 \\
12 & 20 & 18 & $N T$ & 6 & 44 \\
\hline Total & $\mathbf{1 8 4}$ & $\mathbf{1 3 5}$ & $\mathbf{8 3}$ & $\mathbf{1 0 4}$ & $\mathbf{5 0 6}$ \\
\hline
\end{tabular}

$N T$ - Não tem; ** Não compareceu à visita 4 
Na amostra total foram detectados 20 genótipos.

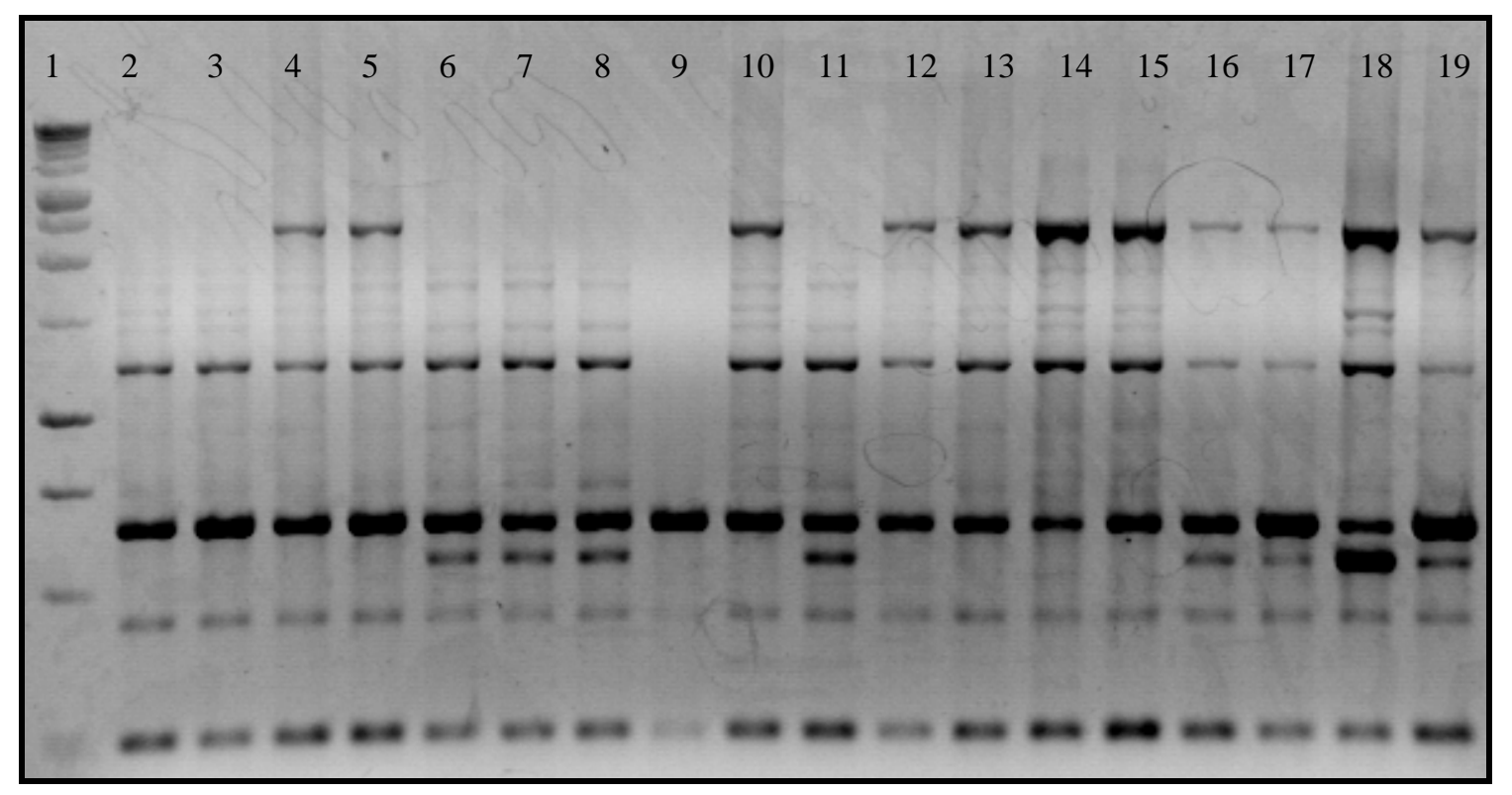

Figura 3 - Fotografia do gel de agarose, onde os produtos de reação de amplificação com o iniciador arbitrário de isolados de S.mutans da família 2 foram submetidos à corrida eletroforética. Linha 1 peso molecular (M) utilizado foi DNA $1 \mathrm{kpb}$; linhas 1 a 7 - isolados da criança (linhas 2 e 3, V2; linhas 4 e 5, V3; linhas 6 e 7, V4); linhas 8 a 11 - isolados da mãe (linha 8, V1; linha 9, V2; linhas 10 e 11, V4); linhas 12 a 15 - isolados do pai (linhas 12 e 13, V1; linhas 14 e 15, V2); Linhas 16 a 19 isolados da agregada (linhas 16 e 17, V1; linhas 18 e 19, V2) 
A tabela 8 apresenta a distribuição dos genótipos de S.mutans nos membros das famílias longitudinalmente. As letras maiúsculas codificam os genótipos adquiridos intrafamilial, não havendo similaridade interfamilial.

Tabela 8 - Distribuição dos genótipos dos Streptococcus mutans identificados durante as visitas

\begin{tabular}{|c|c|c|c|c|c|c|c|c|c|c|c|}
\hline \multirow[t]{2}{*}{ Família } & \multicolumn{3}{|c|}{ Mãe } & \multicolumn{2}{|c|}{ Pai } & \multicolumn{2}{|c|}{ Agregado } & \multicolumn{4}{|c|}{ Criança } \\
\hline & V1 & V2 & V4 & V1 & V2 & V1 & V2 & V1 & V2 & V3 & V4 \\
\hline 1 & $A B$ & $B$ & $A B$ & $A$ & $A$ & $A$ & $A B$ & $a$ & $a$ & $A$ & $A$ \\
\hline 2 & A & B & $A B$ & $A B C$ & $A B C$ & $A B C$ & $A B C$ & $a$ & $A B$ & $A$ & $A B^{* *}$ \\
\hline 4 & $A C$ & $A C$ & $A B C$ & $A B C$ & $A B$ & $A B C$ & $A B C$ & $a$ & $a$ & $A B$ & $A B^{* *}$ \\
\hline 5 & $A B$ & $A B$ & $A B$ & $A B$ & $A B$ & - & - & $a$ & $a$ & $a$ & $A^{* *}$ \\
\hline 7 & $A D$ & $A B C$ & * & $C D$ & * & - & - & $a$ & $A B$ & $a$ & * \\
\hline 8 & $A B$ & $A B$ & A & $A$ & $A B$ & - & - & $a$ & $a$ & $a$ & $A$ \\
\hline 10 & $A B C$ & $A B$ & C & $\mathrm{BD}$ & $B C$ & B & BCDE & $a$ & $a$ & $a$ & $A$ \\
\hline 12 & $\mathrm{ABC}$ & $\mathrm{BC}(F G)$ & * & $\mathrm{AB}(F G)$ & $\mathrm{AC}(F)$ & - & - & $a$ & $a$ & $a$ & $A$ \\
\hline
\end{tabular}

- sem agregada; $f$ - faltou a visita; a cultura negativa para EM

** crianças que apresentaram cárie na última visita; as letras maiúsculas indicam genótipos idênticos dentro da família; Letras F, G representam genótipos de Streptococcus sobrinus compartilhados na Família 12.

Convencionando como estável o genótipo detectado em pelo menos duas ocasiões, em todas as famílias foram encontrados genótipos compartilhados estavelmente pelos adultos, exceto na família 12, sendo que a família 7 ficou prejudicada pelas faltas de seus membros. Entre adultos e crianças somente nas famílias 1, 2 e 4 . Necessitando comprovação longitudinal, quer seja por serem isolados na última visita ou por serem perdidos em visita posterior, alguns genótipos sugerem transmissão possível ou transitória entre adultos (famílias 1,4,8,10,12) e entre adultos e crianças (famílias $5,8,10,12$ ). Apenas um genótipo, o $E$, da agregada da família 10, entre os 20 detectados, não foi compartilhado (Tabelas 9 e 10) 
Tabela 9 - Estabilidade dos genótipos nos membros das 7 famílias

\begin{tabular}{|c|c|c|c|c|c|c|c|}
\hline \multirow[t]{2}{*}{ Família } & \multirow{2}{*}{$\begin{array}{c}\text { Total de } \\
\text { genótipos }\end{array}$} & \multirow[b]{2}{*}{ Membros } & \multicolumn{5}{|c|}{ Genótipos } \\
\hline & & & $A$ & B & C & D & $E$ \\
\hline \multirow{4}{*}{1} & \multirow{4}{*}{2} & $M$ & $E$ & $E$ & - & - & - \\
\hline & & $\mathbf{P}$ & $E$ & - & - & - & - \\
\hline & & A & $E$ & $\mathrm{~N}$ & - & - & - \\
\hline & & C & $E$ & - & - & - & - \\
\hline \multirow{4}{*}{2} & \multirow{4}{*}{4} & M & $E$ & $E$ & - & - & - \\
\hline & & $\mathbf{P}$ & $E$ & $E$ & $\mathrm{E}$ & - & - \\
\hline & & A & $E$ & $E$ & $\mathrm{E}$ & - & - \\
\hline & & C & $E$ & $E$ & - & - & - \\
\hline \multirow{4}{*}{4} & \multirow{4}{*}{2} & $M$ & $E$ & $\mathrm{~N}$ & $\mathrm{E}$ & - & - \\
\hline & & $\mathbf{P}$ & $E$ & $E$ & $\mathrm{P}$ & - & - \\
\hline & & A & $E$ & $E$ & $\mathrm{E}$ & - & - \\
\hline & & C & $E$ & $E$ & - & - & - \\
\hline \multirow{3}{*}{5} & \multirow{3}{*}{2} & $\mathbf{M}$ & $E$ & $E$ & - & - & - \\
\hline & & $\mathbf{P}$ & $E$ & $E$ & - & - & - \\
\hline & & C & $\mathrm{N}$ & - & - & - & - \\
\hline \multirow{3}{*}{8} & \multirow{3}{*}{2} & $\mathbf{M}$ & $E$ & $\mathrm{P}$ & - & - & - \\
\hline & & $\mathbf{P}$ & $E$ & $\mathrm{~N}$ & - & - & - \\
\hline & & C & $N$ & - & - & - & - \\
\hline \multirow{4}{*}{10} & \multirow{4}{*}{4} & M & $E$ & $E$ & $\mathrm{~N}$ & - & - \\
\hline & & $\mathbf{P}$ & - & $E$ & $\mathrm{~N}$ & $P$ & - \\
\hline & & A & - & $E$ & $\mathrm{~N}$ & $N$ & $\mathrm{~N}$ \\
\hline & & C & $\mathrm{N}$ & - & - & - & - \\
\hline \multirow{3}{*}{12} & \multirow{3}{*}{3} & M & $\mathrm{P}$ & $E$ & $E$ & - & - \\
\hline & & $\mathbf{P}$ & $E$ & $\mathrm{P}$ & $\mathrm{N}$ & - & - \\
\hline & & C & $\mathrm{N}$ & - & - & - & - \\
\hline
\end{tabular}

E- estável; $\mathrm{N}$ - novo; $\mathrm{P}$ - perdido 
60 Resultados

Tabela 10 - Transmissão dos genótipos das 7 famílias

\begin{tabular}{|c|c|c|c|c|c|c|c|}
\hline \multirow[b]{2}{*}{ TIPO } & \multicolumn{6}{|c|}{ FAMÍLIAS } & \multirow[b]{2}{*}{12} \\
\hline & 1 & 2 & 4 & 5 & 8 & 10 & \\
\hline \multicolumn{8}{|l|}{ ESTÁVEL } \\
\hline Adulto $\times$ Adulto & A & $A B C$ & $A B C$ & $A B$ & $A$ & $\mathrm{~B}$ & - \\
\hline Adulto x Criança & A & $A B$ & $A B$ & - & - & - & - \\
\hline \multicolumn{8}{|l|}{ POSSÍVEL OU TRANSITÓRIA } \\
\hline Adulto $\times$ Adulto & B & - & $\mathrm{BC}$ & - & $A B$ & $C D$ & $A B C$ \\
\hline Adulto $\times$ Criança & - & - & - & A & $A$ & $A$ & $A$ \\
\hline \multicolumn{8}{|l|}{ SEM TRANSMISSÃO } \\
\hline Agregada & - & - & - & - & - & $E$ & - \\
\hline
\end{tabular}

A tabela 11 retrata a distribuição dos genótipos em membros isolados ou associação de 2 ou mais integrantes.

Tabela 11 - Encontro de genótipos em um ou associação de membros das 8 famílias

\begin{tabular}{|c|c|c|c|c|c|c|c|c|c|}
\hline \multirow{2}{*}{ Membros } & \multicolumn{8}{|c|}{ Famílias } & \multirow{2}{*}{$\begin{array}{l}\text { Total de } \\
\text { Famílias }\end{array}$} \\
\hline & 1 & $2^{\#}$ & $4^{\#}$ & $5^{\#} *$ & $7 *$ & 8* $^{*}$ & 10 & $12^{*}$ & \\
\hline $\bar{M}$ & - & - & - & - & - & - & - & - & 0 \\
\hline $\mathbf{P}$ & - & - & - & - & - & - & - & - & 0 \\
\hline A & - & - & - & - & - & - & - & - & 0 \\
\hline C & - & - & - & - & - & - & - & - & 0 \\
\hline$M \times P$ & - & - & - & B & C,D & $B$ & - & $\mathrm{B}, \mathrm{C}, F, G$ & 4 \\
\hline$M \times A$ & B & - & - & - & - & - & - & - & 1 \\
\hline$M \times C$ & - & - & - & - & $A, B$ & - & A & - & 2 \\
\hline$P \times A$ & - & C & - & - & - & - & $\mathrm{D}$ & - & 2 \\
\hline$P \times C$ & - & - & - & - & - & - & - & - & 0 \\
\hline$A \times C$ & - & - & - & - & - & - & - & - & 0 \\
\hline$M \times P \times A$ & - & - & $\mathrm{C}$ & - & - & - & $\mathrm{B}, \mathrm{C}$ & - & 2 \\
\hline$M \times P \times C$ & - & - & - & A & - & A & - & A & 3 \\
\hline$P \times A \times C$ & - & - & - & - & - & - & - & - & 0 \\
\hline$M \times P \times A \times C$ & $A$ & $A, B$ & $A, B$ & - & - & - & - & - & 3 \\
\hline
\end{tabular}

M - Mãe; P - Pai; A - Agregada; C - Criança; * Família sem agregada; \# crianças com cárie 
A Figura 4 representa as fontes de transmissão dos Streptococcus mutans entre os indivíduos da mesma família, quando a criança está envolvida. A criança compartilhou genótipos com a mãe e o pai em três famílias (modelo I famílias 5, 8 e 12); com a mãe, o pai e a agregada em três famílias (modelo II famílias 1, 2 e 4); somente com a mãe, que por sua vez compartilhava outros genótipos com o pai (modelo III - família 7) e somente com a mãe, que compartilhava outro genótipo só com o pai e outros dois com o pai e a agregada (modelo IV - família 10).

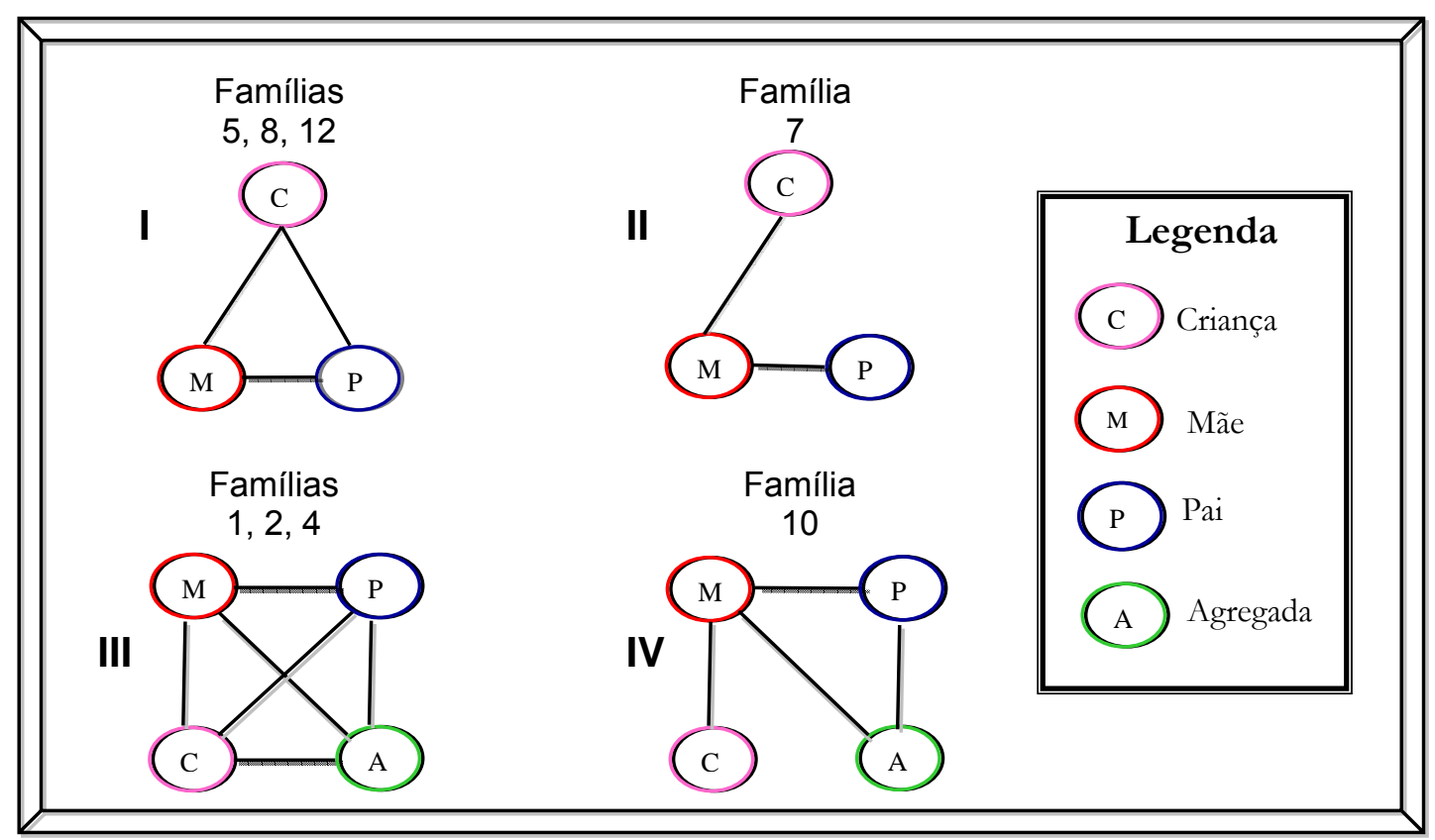

Figura 4 - Transmissão intrafamilial indicado pela similaridade dos genótipos da Tabela 8

Nas oito crianças, que tiveram S. mutans identificados e genotipados, foram encontrados genótipos similares aos maternos em 100\%, similares aos genótipos paternos em $75 \%$ (6/8) e em 75\% (3/4) das agregadas. Todas as mães compartilhavam genótipos com todos os membros da família (Tabela 8).

Não houve correlação entre o número de genótipos e a presença de cárie, pelo teste de Spearman $(p>0,05)$.

A criança da família 5 apresentou Streptococcus sobrinus apenas na Visita 3. Esses isolados não foram genotipados devido à ausência da subespécie nas visitas subseqüentes e nos adultos. Os adultos da Família 12 apresentaram e compartilhavam S. sobrinus, entretanto, este não foi encontrado na criança. 
6. Discussão 


\section{DISCUSSÃO}

Os estudos de transmissão de EM para crianças geralmente envolvem pares de mães e filhos, pelo fato óbvio de maior contato entre eles. Em conseqüência, as medidas preventivas para reduzir a colonização por EM e o desenvolvimento de cárie nas crianças concentram-se na figura materna. Estudos clássicos de KOEHLER et al. (1984) e TENOVUO et al. (1992) demonstraram que o tratamento com gel de clorexidina de mães altamente infectadas por EM reduzia tanto a colonização, como o desenvolvimento de cárie em seus filhos. Analisando a literatura posterior, porém, BRAMBILLA (2004) concluiu que aplicações tópicas de agentes antibacterianos podem reduzir a transmissão de EM de hospedeiro para hospedeiro, mas que isso não resulta necessariamente em menos cárie, daí o interesse em examinar o papel dos demais membros da família nesse quadro.

O exame clínico dos membros das famílias deste estudo revelou, especialmente nas mães e pais, índice CPO-S relativamente alto e leve sangramento gengival $(<2,0)$, compatíveis com a idade da população. Todavia, a presença de superfícies com cárie aberta em todos os membros indica a dificuldade dessas famílias buscarem tratamento, seja pela condição sócio-econômica, seja pela desinformação, fato que assume importância considerável quando se constata que esse grupo faz parte de um universo de $79,9 \%$ da população brasileira que recebem até cinco salários mínimos por mês (IBGE, 2005), e que 50\% das mães tinham apenas o ensino fundamental. PERES et al. (2000) apontam a baixa renda familiar como o principal fator de risco para a cárie, e uma revisão dos recentes modelos multifatoriais de avaliação de risco informa que variáveis sócio-demográficas são 
muito importantes para modelos de previsão para crianças pequenas e adultos mais velhos (POWELL, 1998).

Lesões de cárie não tratadas são uma fonte de EM. Baixos níveis sócio-econômicos (WAN et al., 2001) e de escolaridade da família, como os vistos neste grupo, têm sido relacionados com a colonização precoce e altos níveis de EM na saliva das crianças (KOHLER, ANDREEN, JONSSON, 1984). Significativamente, a colonização por EM foi observada em todas as famílias, com prevalência de $100 \%$ nas mães e agregadas e de $90 \%$ nos pais. Todavia, tem sido sugerido que o maior risco de infecção nas crianças esteja relacionado com níveis salivares altos de EM nas mães (KOHLER, BRATTHALL, KRASSE, 1983; ROETERS et al., 1995; BRAMBILLA et al., 1998; SPOLIDORIO et al., 2003). Escores médios de EM $\geq 10^{5} \mathrm{UFC/ml}$ de saliva foram observados em 12 das 14 mães. Esses níveis são compatíveis com maior risco de transmissão da infecção para as crianças (KOHLER, BRATTHALL, 1978). Mas não apenas isso: essas mães apresentaram escores de EM significantemente maiores que os dos pais e agregadas, continuando, com raras exceções, como um grupo de alto risco de cárie para elas mesmas, e de alto risco para a transmissão de EM como já o eram no momento da seleção da amostra. Outra observação, que se faz no grupo, é a de que altos níveis de EM nas mães não implicam, necessariamente, em automática colonização dos filhos, conforme visto no caso da mãe da família 13 e já constatado por outros (KOHLER; BRATTHALL, 1978; EMANUELSSON, LI, BRATTHALL, 1998).

Posto que houvesse vários aspectos comuns entre essas famílias, a colonização pelos EM e o desenvolvimento de cárie em seus primogênitos foram heterogêneos, em conformidade com a complexidade dos eventos da transmissão, que incluem não apenas o número de microrganismos disponíveis para aderir, mas também sua afinidade pelo hospedeiro, a freqüência de transferência, fatores do hospedeiro que interferem na aderência ou crescimento bacteriano, sobrevivência bacteriana durante a transferência, tipo de dieta do hospedeiro (VAN HOUTE, GREEN,1974), o tipo de parto (LI et al., 2005) ou a duração e intensidade da amamentação (LI, WANG, CAUFIELD, 2000).

Nas quatro visitas, respectivamente uma, duas, três e dez crianças mostraram-se positivas para EM, confirmando que o número de crianças colonizadas aumenta com a idade (KOHLER; BRATTHALL, KRASSE, 1983). Todavia, nenhuma diferença foi encontrada entre o momento de detecção e o 
número de dentes nessas crianças, contrariando outros autores (CARLSSON, GRAHNEN, JONSSON, 1975; MASUDA et al., 1979; ALALUUSUA, RENKONEN, 1983; KLEIN et al., 2004). É preciso, porém, exercer extrema cautela na leitura dos resultados estatísticos quanto a todos os aspectos pesquisados, em face do pequeno tamanho da amostra.

A colonização de $21 \%$ das crianças pelos EM aos 19 meses de idade, e de $82 \%$, aos 29-30 meses de idade, corrobora o conceito da "primeira janela da infectividade", apregoado por CAUFIELD, CUTTER, DASANAYAKE. (1993). Nesse grupo especial, não houve a aquisição mais precoce relatada para as crianças brasileiras por KLEIN et al.(2004)

Os EM podem ser detectados na boca antes da irrupção dos dentes (MILGROM et al., 2000; TANNER et al., 2002), o que foi aqui constatado, com a observação de três crianças positivas para EM (\# 2, 4 e 7), antes de um ano de idade, com níveis variando de 280 a 600 UFC/ml de saliva, geralmente considerados como de colonização transitória (CARLSSON et al., 1970; 1975; BERKOWITZ et al., 1975; 1980; MASUDA et al., 1979; ALALUUSUA, RENKONEN, 1983; DAVEY, ROGERS, 1984; FUJIWARA et al., 1991; ALALUUSUA et al., 1996). Todavia, duas dessas crianças foram densamente colonizadas por EM na visita 3, e mantiveram a colonização na visita 4. Coincidentemente, ambas exibiram cárie dental aos 30 meses de idade, uma indicação de que as crianças colonizadas mais precocemente podem apresentar maior suscetibilidade à cárie dental (ALALUUSUA, RENKONEN, 1983; KOHLER, BRATTHALL, 1978; KOHLER ET AL, 1988), e que, certamente nesses dois casos a infecção não foi transitória. Essa observação torna-se ainda mais grave, quando a literatura aponta que com a colonização precoce é maior a probabilidade de desenvolvimento de cáries nos anos seguintes (KOHLER et al., 1988; THIBODEAU, SULLIVAN, 1995). A outra criança que apresentou cárie (\# 5) só veio a exibir altos níveis de EM (704.000 UFC/ml de saliva) na visita 4. Todavia, essa criança teve irrupção mais precoce dos seus dentes (13 dentes na visita 3 ) quando comparada com a das demais. A presença de cárie apenas nas crianças colonizadas confirma também a assertiva de que a doença é mais freqüente em crianças colonizadas do que nas não colonizadas por EM (ALALUUSUA, RENKONEN, 1983; FUJIWARA et al, 1991).

A explicação para a presença de cárie ou sua ausência não pôde ser atribuída aos níveis de cárie ou de EM das mães, que não diferiram 
significantemente, conquanto quase todas preenchessem o quesito de $>10^{5} \mathrm{EM} / \mathrm{ml}$ de saliva. Pelo menos em parte, porém, a explicação estaria nos níveis de EM significantemente maiores das crianças com cárie na última visita, confirmando estudo de MATTOS-GRANER et al. (1998). Nenhuma das outras variáveis pesquisadas (gênero, raça, tempo de amamentação, uso de açúcar, tipo de parto, número de hábitos de risco) apontou qualquer diferença entre os dois grupos.

Diferentes estudos, usando técnicas como a bacteriocinotipagem (BERKOWITZ, JORDAN, 1975; MASUDA et al., 1979; DAVEY, ROGERS, 1984; AZEVEDO, ZELANTE, 1994; GRONROOS et al., 1998), ou sorotipagem (BERKOWITZ et al., 1975; MASUDA et al., 1979; Ll et al., 2001) apontaram a mãe como a principal fonte de infecção de EM para os filhos. O primeiro estudo de genotipagem a sugerir que as bactérias são transmitidas verticalmente de mãe para filho, mostrando em três pares de mãe e filho que todas as crianças adquiriram um genótipo idêntico ao materno, foi realizado por CAUFIELD, WALKER (1989), que demonstraram ainda a estabilidade de colonização em um dos pares, com o reisolamento de genótipos após intervalo de três anos. Estudos mais abrangentes (CAUFIELD, CUTTER, DASANAYAKE, 1993; LI, CAUFIELD, 1995) confirmaram a fidelidade de transmissão. Cepas de EM coincidentes com as das mães foram detectadas em mais de $70 \%$ dos pares de mães e filhos estudados por LI, CAUFIELD (1995), para os quais, a fidelidade de transmissão poderia ser ainda maior, se o número de isolados fosse maior. Essa freqüência de similaridade varia, porém, entre as populações, onde as práticas culturais podem influenciar o grau de contato entre as crianças, os pais e outros indivíduos (LI, CAUFIELD, 1995; REDMOEMANUELSSON, WANG, 1998; EMANUELSSON, LI, BRATTHALL, 1998; KLEIN et al., 2004).

Para CAUFIELD (1997), a criança deve adquirir vários microrganismos indígenas de sua mãe, que são complementares aos fatores imunes transferidos passivamente. Dessa forma, crianças adotadas logo após o nascimento poderiam ter diferente suscetibilidade a doenças infecciosas, inclusive cárie, devido às diferenças na aquisição da microbiota indígena de suas mães. FIGUEIREDO et al. (2000), investigando pares de mães e filhos adotivos, observaram genótipos homólogos em apenas $19 \%$ dos filhos. Oitenta e um por cento dos mesmos foram colonizados por EM diferentes dos das mães e muitos não apresentavam lesões cariosas e, se as possuíssem, estavam presentes em menos de $25 \%$ das superfícies dentárias. 
Genótipos idênticos aos maternos foram encontrados em 100\% das crianças cujos isolados foram genotipados neste estudo, sendo a mãe, portanto, a principal fonte de infecção da amostra. Coincidência alta (81\%) de genótipos de S.mutans em pares de mães e filhos foi verificada também em outra pesquisa feita no Brasil (KLEIN et al., 2004). Essa fidelidade genotípica entre mães e filhos parece estar relacionada com a freqüência de contato e com o nível de S.mutans.

Enquanto o encontro de cepas similares de EM em mães e filhos indica uma linha materna para a transmissão, a pesquisa de genótipos similares entre pais e filhos ou pais e mães mostra resultados negativos (Li, Caufield, 1995; 1998; EMANUELSSON, LI, BRATTHALL, 1998; REDMO EMANUELSSON, THORNQUIST, 2001), ou positivos (KULKARNI et al., 1989; SAARELA et al., 1993; REDMO EMANUELSSON, WANG, 1998; KOZAl et al., 1999; TEDJOSASONGKO, KOZAI, 2002; SPOLIDORIO et al., 2003; ERSIN et al., 2004). No estudo feito com onze famílias chinesas, REDMO EMANUELSSON, WANG (1998) encontraram genótipos idênticos entre mães e filhos, pais e filhos e também entre esposos, com maior similaridade entre mães e filhos. Sem mencionar o total de genótipos detectados nos 374 isolados de membros de vinte e duas famílias brasileiras, nem a similaridade dos genótipos nos adultos, SPOLIDORIO et al. (2003) encontraram 12 bebês $(54,5 \%)$ com genótipos de S.mutans similares aos maternos, 3 (14\%) com genótipos homólogos aos paternos e 7(32\%) com genótipos homólogos aos dos irmãos. Esse compartilhamento de cepas de S.mutans em famílias brasileiras, já fora observado através de bacteriocinotipagem por AZEVEDO, ZELANTE, em 1994.

Neste estudo, num total de 506 isolados, foram detectados 20 genótipos diferentes com ampla difusão dos mesmos entre os membros das famílias, reflexo provavelmente da maior proximidade das pessoas e do compartilhamento de utensílios que se pode prever em lares de famílias de baixa renda. Conforme observado nos modelos da Figura 4, além dos genótipos homólogos aos da mãe, as crianças compartilharam genótipos com os pais e agregadas, que por sua vez compartilhavam-nos com as mães. É interessante esse compartilhamento de genótipos com as agregadas. No Japão, não foi observada transmissão por cuidadoras outras que as mães (TEDJOSASONGKO E KOZAI, 2002). Convencionalmente, foi estipulado que o encontro do genótipo em duas ocasiões sucessivas ou não, seria indicação de colonização estável, e a perda ou aquisição recente, como indicação de colonização transitória ou possível, dada a 
impossibilidade de determiná-la, em face do término do trabalho. O fato de os genótipos serem encontrados em todas as famílias antes de sua detecção na criança dá suporte à transmissão com direção única Adulto - Criança. $O$ não encontro de genótipos alheios à família comprova que essas crianças cuidadas em casa não abrigam cepas provenientes de fontes alternativas desconhecidas, conforme visto por outros autores (KULKARNI et al., 1989; KOZAl et al., 1999; LI, CAUFIELD, 1995; EMANUELSSON, LI, BRATTHALL, 1998; TEDJOSASONGKO, KOZAI, 2002; LINDQUIST, EMILSON, 2004), ou conhecidas, como creches (MATTOS GRANER et al.2001; TEDJOSASONGKO, KOZAI, 2002; LIU et al., 2007).

De modo geral, crianças de até três anos podem abrigar de 1 a 4 genótipos (CAUFIELD, WALKER, 1989; GRONROOS et al., 1998; REDMO EMANUELSSON, WANG, 1998; EMANUELSSON, LI, BRATTHALL, 1998; KOZAl et al., 1999; MATTOS GRANER et al., 2001; KLEIN et al., 2004), e os adultos são colonizados por múltiplos clones de EM, verificando-se estabilidade da colonização por longo tempo (CAUFIELD, WALKER, 1989; GRONROOS et al., 1995; 1998; EMANUELSSON, THORNQUIST, 2000; REDMO EMANUELSSON et al. 2003; NAPIMOGA et al., 2004). Nesse estudo, o número de genótipos entre os adultos variou de 1 a 5 e entre as crianças de 1 a 2 conforme a literatura, observando-se estabilidade de alguns e flutuação no encontro de outros genótipos. O fato da maioria das crianças apresentar S.mutans apenas na última visita, impediu que se visualizasse o aumento na diversidade de genótipos nas mesmas, verificado por KLEIN et al.(2004).

Nem todos os genótipos, mesmos os maternos se implantaram nas crianças. ALALUUSUA et al. (1996) apontam as possíveis explicações para as crianças apresentarem menos genótipos que suas mães: o maior número de oportunidades de transmissão para as mães ao longo dos anos; maior número de fontes de infecção dos membros de suas famílias e seus companheiros, que as crianças de hoje, uma vez que a prevalência de cárie diminuiu; um reflexo, talvez, do maior nível de EM em sua infância.

Em crianças com cárie, nenhuma associação significante foi observada entre a diversidade genotípica do microrganismo e a idade, número de dentes irrompidos, níveis de EM, ou prevalência de cárie (MATTOS-GRANER et al., 2001), mas a presença de múltiplos genótipos já foi associada à alta atividade de cárie (ALALUUSUA et al., 1996; LIU et al., 2007). Duas das três crianças com cárie aqui 
estudadas apresentaram dois genótipos. Além delas, apenas uma criança (\# 7), da qual não foi feita a avaliação final de cárie, por não comparecer, apresentou dois genótipos na visita 2. As demais exibiram um único genótipo.

O estudo da diversidade genética é limitado pelo custo do processamento laboratorial, o que dificulta a pesquisa de maior número de isolados que favorece maior detecção de genótipos. Para aumentar a precisão dos resultados, o número de isolados examinados em cada família, embora o número utilizado seja compatível com o pesquisado por outros autores, deveria ser maior, bem como se poderia acrescentar o exame de isolados da placa, visto que genótipos de S.mutans podem colonizar seletivamente sítios específicos dos dentes (GRONROOS, ALALUUSUA, 2000; REDMO EMANUELSSON et al., 2003; KLEIN et al., 2004). O exame da saliva sozinha, como tem sido feito pela maioria dos autores, é suficiente para estudar os genótipos mais prevalentes, e, portanto, os mais aptos, e talvez, mais virulentos.

As famílias das três crianças com cárie exibiram compartilhamento de genótipos entre todos os membros (modelos I e II, da Figura 4). As mães, como fonte principal de transmissão, têm sido alvo de medidas preventivas que visam retardar a reaquisição de EM e diminuir a prevalência de cárie nas crianças. Este trabalho demonstra, a partir da avaliação de um grupo pequeno, que em famílias de baixa renda, cujas condições de moradia não são ideais, é freqüente a difusão de genótipos das mães para outros membros. Dessa forma, a explicação pelo insucesso de alguns dos programas preventivos de redução de cárie nas crianças, com medidas aplicadas exclusivamente nas mães, poderia estar na facilidade de reinfecção, pela intensa transmissão intrafamiliar. Para atingir o objetivo, os programas que preconizam o uso intensivo de antimicrobianos em mães de famílias de baixa renda, deveriam se estender aos demais familiares. 
7 Conclusões 


\section{CONCLUSÕES}

Em famílias de baixa renda, cujos primogênitos são cuidados em casa pela mãe, pai e eventual agregada, são encontrados genótipos homólogos em todos os membros. Mesmo sendo a mãe a principal fonte de infecção para a criança, há também a transmissão de genótipos que são compartilhados pelos adultos, o que deve favorecer a reinfecção por esses genótipos, quando de uma eventual perda. Não foram encontrados genótipos de origem extrafamilial. 
Referências Bibliográficas 
ALALUUSUA, S, RENKONEN, OV. Streptococcus mutans establishment and dental caries experience in children from 2 to 4 years old. Scand J Dent Res. 1983 Dec;91(6):453-7.

ALALUUSUA, S, NYSTROM, M, GRONROOS, L, PECK, L. Caries-related microbiological findings in a group of teenagers and their parents. Caries Res. 1989;23(1):49-54.

ALALUUSUA, S, MYLLARNIEMI, S, KALLIO, M, SALMENPERA, L, TAINIO, VM. Prevalence of caries and salivary levels of mutans streptococci in 5-year-old children in relation to duration of breast feeding. Scand J Dent Res. 1990 Jun;98(3):193-6.

ALALUUSUA, S, ALALUUSUA, SJ, KARJALAINEN, J, SAARELA, M, HOLTTINEN, T, KALLIO, M, et al. The demonstration by ribotyping of the stability of oral Streptococcus mutans infection over 5 to 7 years in children. Arch Oral Biol. 1994 Jun;39(6):467-71.

ALALUUSUA, S, MATTO, J, GRONROOS, L, INNILA, S, TORKKO, H, ASIKAINEN, $\mathrm{S}$, et al. Oral colonization by more than one clonal type of mutans streptococcus in children with nursing-bottle dental caries. Arch Oral Biol. 1996 Feb;41(2):16773.

ANDRADE, J. Comparação entre teste BANA e Checkerboard DNA-DNA Hybridization no diagnóstico periodontal inicial e no monitoramento terapêutico Guarulhos, São Paulo: Universidade de Guarulhos; 2005.

AZEVEDO, R. O emprego da bacteriociotipagem (mutacinotipagem) no rastreamento epidemiológico de estreptococos do "grupo mutans". São Paulo, 1988. / Tese Doutorado - Instituto de Ciências Biomédicas. São Paulo: Universidade de São Paulo; 1988.

AZEVEDO, RV, ZELANTE, F. Streptococci of the mutans group: confirmation of intrafamilial transmission by mutacin typing. Braz Dent J. 1994;5(1):27-34.

BARONE, S, MACEDO, C, MARIN, JM. Arbitrarily primed polymerase chain reaction for fingerprinting the genotype identification of mutans streptococci in children with Down syndrome. Spec Care Dentist. 2005 Jan-Feb;25(1):37-42.

BECKER, MR, PASTER, BJ, LEYS, EJ, MOESCHBERGER, ML, KENYON, SG, GALVIN, JL, et al. Molecular analysis of bacterial species associated with childhood caries. J Clin Microbiol. 2002 Mar;40(3):1001-9. 
BERKOWITZ, RJ, JORDAN, HV, WHITE, G. The early establishment of Streptococcus mutans in the mouths of infants. Arch Oral Biol. 1975 Mar;20(3):171-4.

BERKOWITZ, RJ, TURNER, J, GREEN, P. Primary oral infection of infants with Streptococcus mutans. Arch Oral Biol. 1980;25(4):221-4.

BRAMBILLA, E, FELLONI, A, GAGLIANI, M, MALERBA, A, GARCIA-GODOY, F, STROHMENGER, L. Caries prevention during pregnancy: results of a 30-month study. J Am Dent Assoc. 1998 Jul;129(7):871-7.

BRAMBILLA, E, CAGETTI, MG, FADINI, L, PARISET, P, STROHMENGER, L, TWETMAN, S. Chlorhexidine concentration in saliva after topical treatment with an antibacterial dental varnish. Am J Dent. 2004 Jun;17(3):196-8.

CARLSSON, J, SODERHOLM, G, ALMFELDT, I. Prevalence of Streptococcus sanguis and Streptococcus mutans in the mouth of persons wearing fulldentures. Arch Oral Biol. 1969 Mar;14(3):243-9.

CARLSSON, J, GRAHNEN, H, JONSSON, G, WIKNER, S. Establishment of Streptococcus sanguis in the mouths of infants. Arch Oral Biol. 1970 Dec;15(12):1143-8.

CARLSSON, J, GRAHNEN, H, JONSSON, G. Lactobacilli and streptococci in the mouth of children. Caries Res. 1975;9(5):333-9.

CAUFIELD, PW, WALKER, TM. Genetic diversity within Streptococcus mutans evident from chromosomal DNA restriction fragment polymorphisms. J Clin Microbiol. 1989 Feb;27(2):274-8.

CAUFIELD, PW, CUTTER, GR, DASANAYAKE, AP. Initial acquisition of mutans streptococci by infants: evidence for a discrete window of infectivity. J Dent Res. 1993 Jan;72(1):37-45.

CAUFIELD, PW, RATANAPRIDAKUL, K, ALLEN, DN, CUTTER, GR. Plasmidcontaining strains of Streptococcus mutans cluster within family and racial cohorts: implications for natural transmission. Infect Immun. 1988 Dec;56(12):3216-20.

CAUFIELD, PW. Dental caries--a transmissible and infectious disease revisited: a position paper. Pediatr Dent. 1997 Nov-Dec;19(8):491-8.

CAUFIELD, PW. Dental caries: an infectious and transmissible disease where have we been and where are we going? N Y State Dent J. 2005 Mar;71(2):23-7. 
COGULU, D, SABAH, E, UZEL, A, OZKINAY, F. Genotyping of Streptococcus mutans by using arbitrarily primed polymerase chain reaction in children with Down Syndrome. Arch Oral Biol. 2006 Mar;51(3):177-82.

DAVEY, AL, ROGERS, AH. Multiple types of the bacterium Streptococcus mutans in the human mouth and their intra-family transmission. Arch Oral Biol. 1984;29(6):453-60.

EMANUELSSON, IR, LI, Y, BRATTHALL, D. Genotyping shows different strains of mutans streptococci between father and child and within parental pairs in Swedish families. Oral Microbiol Immunol. 1998 Oct;13(5):271-7.

EMANUELSSON, IR, THORNQVIST, E. Genotypes of mutans streptococci tend to persist in their host for several years. Caries Res. 2000 Mar-Apr;34(2):133-9.

EMILSON, CG, KRASSE, B. Comparison between a dip-slide test and plate count for determination of Streptococcus mutans infection. Scand J Dent Res. 1986 Dec;94(6):500-6.

ERSIN, NK, KOCABAS, EH, ALPOZ, AR, UZEL, A. Transmission of Streptococcus mutans in a group of Turkish families. Oral Microbiol Immunol. 2004 Dec;19(6):408-10.

FEINBERG, AP, VOGELSTEIN, B. A technique for radiolabeling DNA restriction endonuclease fragments to high specific activity. Anal Biochem. 1983 Jul 1;132(1):6-13.

FIGUEIREDO, MC, REIS, IC, CAUFIELD, PW. Transmissibilidade da doença cárie entre mães e filhos adotivos. Jornal da ABOPREV. 2000;10:3-4.

FLORIO, FM, KLEIN, MI, PEREIRA, AC, GONCALVES, BR. Time of initial acquisition of mutans streptococci by human infants. J Clin Pediatr Dent. 2004 Summer;28(4):303-8.

FUJIWARA, T, NAKANO, K, KAWAGUCHI, M, OOSHIMA, T, SOBUE, S, KAWABATA, $S$, et al. Biochemical and genetic characterization of serologically untypable Streptococcus mutans strains isolated from patients with bacteremia. Eur J Oral Sci. 2001 Oct;109(5):330-4.

GARN, SM, ROWE, NH, CLARK, DC. Parent-child similarities in dental caries rates. J Dent Res. 1976 Nov-Dec;55(6):1129.

GOLD, OG, JORDAN, HV, VAN HOUTE, J. A selective medium for Streptococcus mutans. Arch Oral Biol. 1973 Nov;18(11):1357-64. 
GRACIANO, MI, LEHFELD, NAS, NEVES FILHO, A. Critérios de avaliação para classificação sócia-econômica: elementos de atualização - Parte II. Serviço Social e Realidade (Franca). 1996;5:171-201.

GRONROOS, L, ALALUUSUA, S. Site-specific oral colonization of mutans streptococci detected by arbitrarily primed PCR fingerprinting. Caries Res. 2000 Nov-Dec;34(6):474-80.

GRONROOS, L, MATTO, J, SAARELA, M, LUOMA, AR, LUOMA, H, JOUSIMIESSOMER, $\mathrm{H}$, et al. Chlorhexidine susceptibilities of mutans streptococcal serotypes and ribotypes. Antimicrob Agents Chemother. 1995 Apr;39(4):894-8.

GRONROOS, L, SAARELA, M, MATTO, J, TANNER-SALO, U, VUORELA, A, ALALUUSUA, S. Mutacin production by Streptococcus mutans may promote transmission of bacteria from mother to child. Infect Immun. 1998 Jun;66(6):2595-600.

HAMES-KOCABAS, EE, UCAR, F, KOCATAS ERSIN, N, UZEL, A, ALPOZ, AR. Colonization and vertical transmission of Streptococcus mutans in Turkish children. Microbiol Res. 2006 May 28.

KARN, TA, O'SULLIVAN, DM, TINANOFF, N. Colonization of mutans streptococci in 8- to 15-month-old children. J Public Health Dent. 1998 Summer;58(3):248-9.

KLEIN, MI. Transmissão, diversidade e estabilidade de genótipos de Streptococcus mutans e de Streptococcus sobrinus: estudo longitudinal em crianças. Piracicaba: Universidade de Campinas; 2003.

KLEIN, MI, FLORIO, FM, PEREIRA, AC, HOFLING, JF, GONCALVES, RB. Longitudinal study of transmission, diversity, and stability of Streptococcus mutans and Streptococcus sobrinus genotypes in Brazilian nursery children. J Clin Microbiol. 2004 Oct;42(10):4620-6.

KOHLER, B, BRATTHALL, D. Intrafamilial levels of Streptococcus mutans and some aspects of the bacterial transmission. Scand J Dent Res. 1978 Jan;86(1):35-42.

KOHLER, B, ANDREEN, I, JONSSON, B. The effect of caries-preventive measures in mothers on dental caries and the oral presence of the bacteria Streptococcus mutans and lactobacilli in their children. Arch Oral Biol. 1984;29(11):879-83.

KOHLER, B, ANDREEN, I, JONSSON, B. The earlier the colonization by mutans streptococci, the higher the caries prevalence at 4 years of age. Oral Microbiol Immunol. 1988 Mar;3(1):14-7. 
KOHLER, B, BRATTHALL, D, KRASSE, B. Preventive measures in mothers influence the establishment of the bacterium Streptococcus mutans in their infants. Arch Oral Biol. 1983;28(3):225-31.

KOZAI, K, NAKAYAMA, R, TEDJOSASONGKO, U, KUWAHARA, S, SUZUKI, J, OKADA, M, et al. Intrafamilial distribution of mutans streptococci in Japanese families and possibility of father-to-child transmission. Microbiol Immunol. 1999;43(2):99-106.

KULKARNI, GV, CHAN, KH, SANDHAM, HJ. An investigation into the use of restriction endonuclease analysis for the study of transmission of mutans streptococci. J Dent Res. 1989 Jul;68(7):1155-61.

LEMBO, F. Análise genotípica e fenotípica de isolados de Streptococcus mutans provenientes de diferentes nichos da cavidade bucal de crianças livres de cárie e cárie ativas. São Paulo: Universidade de São Paulo; 2005.

LI, Y, CAUFIELD, PW. The fidelity of initial acquisition of mutans streptococci by infants from their mothers. J Dent Res. 1995 Feb;74(2):681-5.

LI, Y, CAUFIELD, PW. Arbitrarily primed polymerase chain reaction fingerprinting for the genotypic identification of mutans streptococci from humans. Oral Microbiol Immunol. 1998 Feb;13(1):17-22.

LI, Y, WANG, W, CAUFIELD, PW. The fidelity of mutans streptococci transmission and caries status correlate with breast-feeding experience among Chinese families. Caries Res. 2000 Mar-Apr;34(2):123-32.

LI, Y, CAUFIELD, PW, EMANUELSSON, IR, THORNQVIST, E. Differentiation of Streptococcus mutans and Streptococcus sobrinus via genotypic and phenotypic profiles from three different populations. Oral Microbiol Immunol. 2001 Feb;16(1):16-23.

LI, Y, CAUFIELD, PW, DASANAYAKE, AP, WIENER, HW, VERMUND, SH. Mode of delivery and other maternal factors influence the acquisition of Streptococcus mutans in infants. J Dent Res. 2005 Sep;84(9):806-11.

LI, Y, GE, Y, SAXENA, D, CAUFIELD, PW. Genetic profiling of the oral microbiota associated with severe early-childhood caries. J Clin Microbiol. 2007 Jan;45(1):81-7.

LINDQUIST, B, EMILSON, CG. Colonization of Streptococcus mutans and Streptococcus sobrinus genotypes and caries development in children to mothers harboring both species. Caries Res. 2004 Mar-Apr;38(2):95-103. 
LIU, Y, ZOU, J, SHANG, R, ZHOU, XD. Genotypic diversity of Streptococcus mutans in 3- to 4-year-old Chinese nursery children suggests horizontal transmission. Arch Oral Biol. 2007 Apr 25.

LOE, H. The Gingival Index, the Plaque Index and the Retention Index Systems. J Periodontol. 1967 Nov-Dec;38(6):Suppl:610-6.

LOESCHE, WJ. Clinical and microbiological aspects of chemotherapeutic agents used according to the specific plaque hypothesis. J Dent Res. 1979 Dec;58(12):2404-12.

LOESCHE, WJ. Role of Streptococcus mutans in human dental decay. Microbiol Rev. 1986 Dec;50(4):353-80.

MASUDA, N, TSUTSUMI, N, SOBUE, S, HAMADA, S. Longitudinal survey of the distribution of various serotypes of Streptococcus mutans in infants. J Clin Microbiol. 1979 Oct;10(4):497-502.

MATTOS-GRANER, RO, ZELANTE, F, LINE, RC, MAYER, MP. Association between caries prevalence and clinical, microbiological and dietary variables in 1.0 to 2.5-year-old Brazilian children. Caries Res. 1998;32(5):319-23.

MATTOS-GRANER, RO, LI, Y, CAUFIELD, PW, DUNCAN, M, SMITH, DJ. Genotypic diversity of mutans streptococci in Brazilian nursery children suggests horizontal transmission. J Clin Microbiol. 2001 Jun;39(6):2313-6.

MILGROM, P, RIEDY, CA, WEINSTEIN, P, TANNER, AC, MANIBUSAN, L, BRUSS, $J$. Dental caries and its relationship to bacterial infection, hypoplasia, diet, and oral hygiene in 6- to 36-month-old children. Community Dent Oral Epidemiol. 2000 Aug;28(4):295-306.

MINAH, GE, SOLOMON, ES, CHU, K. The association between dietary sucrose consumption and microbial population shifts at six oral sites in man. Arch Oral Biol. 1985;30(5):397-401.

NAKANO, K, NOMURA, R, SHIMIZU, N, NAKAGAWA, I, HAMADA, S, OOSHIMA, T. Development of a PCR method for rapid identification of new Streptococcus mutans serotype k strains. J Clin Microbiol. 2004 Nov;42(11):4925-30.

NAPIMOGA, MH, KAMIYA, RU, ROSA, RT, ROSA, EA, HOFLING, JF, MATTOSGRANER, RO, et al. Genotypic diversity and virulence traits of Streptococcus mutans in caries-free and caries-active individuals. J Med Microbiol. 2004 Jul;53(Pt 7):697-703. 
NAPIMOGA, MH, HOFLING, JF, KLEIN, MI, KAMIYA, RU, GONCALVES, RB. Tansmission, diversity and virulence factors of Sreptococcus mutans genotypes. J Oral Sci. 2005 Jun;47(2):59-64.

NASCIMENTO, MM, HOFLING, JF, GONCALVES, RB. Streptococcus mutans genotypes isolated from root and coronal caries. Caries Res. 2004 SepOct;38(5):454-63.

NIE, M, FAN, M, BIAN, Z. Transmission of mutans streptococci in adults within a Chinese population. Caries Res. 2002 May-Jun;36(3):161-6.

NOCE, E. Aquisição de Estreptococos mutans e periodontopatógenos por primogênitos de 7-19 meses de idade. Estudo longitudinal em famílias. Bauru: Universidade de São Paulo; 2005.

PERES, KDA, BASTOS JRM, LATORRE MRDO. Severidade de cárie em crianças e relação com aspectos sociais e comportamentais. Rev Saude Publica. 2000;34:402-8.

POWELL, LV. Caries prediction: a review of the literature. Community Dent Oral Epidemiol. 1998 Dec;26(6):361-71.

REDMO EMANUELSSON, IM, WANG, XM. Demonstration of identical strains of mutans streptococci within Chinese families by genotyping. Eur J Oral Sci. 1998 Jun;106(3):788-94.

REDMO EMANUELSSON, IM, THORNQVIST, E. Distribution of mutans streptococci in families: a longitudinal study. Acta Odontol Scand. 2001 Apr;59(2):93-8.

REDMO EMANUELSSON, IM, CARLSSON, P, HAMBERG, K, BRATTHALL, D. Tracing genotypes of mutans streptococci on tooth sites by random amplified polymorphic DNA (RAPD) analysis. Oral Microbiol Immunol. 2003 Feb;18(1):249.

ROETERS, FJ, VAN DER HOEVEN, JS, BURGERSDIJK, RC, SCHAEKEN, MJ. Lactobacilli, mutants streptococci and dental caries: a longitudinal study in 2year-old children up to the age of 5 years. Caries Res. 1995;29(4):272-9.

ROSA, OPS, SANCHES, FAC. Transmissibilidade de Estreptococos mutans de mãe para filho e prevenção. Revista Dental Press de Biologia Oral. 2000;1(1):37-50.

SAARELA, M, ALALUUSUA, S, TAKEI, T, ASIKAINEN, S. Genetic diversity within isolates of mutans streptococci recognized by an rRNA gene probe. J Clin Microbiol. 1993 Mar;31(3):584-7. 
SAARELA, M, HANNULA, J, MATTO, J, ASIKAINEN, S, ALALUUSUA, S. Typing of mutans streptococci by arbitrarily primed polymerase chain reaction. Arch Oral Biol. 1996 Aug-Sep;41(8-9):821-6.

SIQUEIRA, JF, JR., ROCAS, IN, SOUTO, R, UZEDA, M, COLOMBO, AP. Microbiological evaluation of acute periradicular abscesses by DNA-DNA hybridization. Oral Surg Oral Med Oral Pathol Oral Radiol Endod. 2001 Oct;92(4):451-7.

SOCRANSKY, SS, HAFFAJEE, AD, SMITH, C, MARTIN, L, HAFFAJEE, JA, UZEL, NG, et al. Use of checkerboard DNA-DNA hybridization to study complex microbial ecosystems. Oral Microbiol Immunol. 2004 Dec;19(6):352-62.

SPOLIDORIO, D, HÖFLING, J, PIZZOLITTO, A, ROSA, EA, NEGRINI, T, SPOLIDORIO, L. Genetic polymorphism of Streptococcus mutans in Brazilian family members. Brazilian Journal of Microbiology. 2003;34:213-7.

TANNER, AC, MILGROM, PM, KENT, R, JR., MOKEEM, SA, PAGE, RC, LIAO, SI, et al. Similarity of the oral microbiota of pre-school children with that of their caregivers in a population-based study. Oral Microbiol Immunol. 2002 Dec;17(6):379-87.

TEDJOSASONGKO, U, KOZAI, K. Initial acquisition and transmission of mutans streptococci in children at day nursery. ASDC J Dent Child. 2002 SepDec;69(3):284-8, 34-5.

TENOVUO, J, HAKKINEN, P, PAUNIO, P, EMILSON, CG. Effects of chlorhexidinefluoride gel treatments in mothers on the establishment of mutans streptococci in primary teeth and the development of dental caries in children. Caries Res. 1992;26(4):275-80.

THIBODEAU, EA, O'SULLIVAN, DM. Salivary mutans streptococci and incidence of caries in preschool children. Caries Res. 1995;29(2):148-53.

VAN BELKUM, A. DNA fingerprinting of medically important microorganisms by use of PCR. Clin Microbiol Rev. 1994 Apr;7(2):174-84.

VAN HOUTE, J, GREEN, DB. Relationship between the concentration of bacteria in saliva and the colonization of teeth in humans. Infect Immun. 1974 Apr;9(4):62430.

VAN HOUTE, J. Microbiological predictors of caries risk. Adv Dent Res. 1993 Aug;7(2):87-96. 
WAN, AK, SEOW, WK, PURDIE, DM, BIRD, PS, WALSH, LJ, TUDEHOPE, DI. Oral colonization of Streptococcus mutans in six-month-old predentate infants. J Dent Res. 2001 Dec;80(12):2060-5.

WELSH, J, MCCLELLAND, M. Fingerprinting genomes using PCR with arbitrary primers. Nucleic Acids Res. 1990 Dec 25;18(24):7213-8.

WENNERHOLM, K, BIRKHED, D, EMILSON, CG. Effects of sugar restriction on Streptococcus mutans and Streptococcus sobrinus in saliva and dental plaque. Caries Res. 1995;29(1):54-61.

WILLIAMS, JG, KUBELIK, AR, LIVAK, KJ, RAFALSKI, JA, TINGEY, SV. DNA polymorphisms amplified by arbitrary primers are useful as genetic markers. Nucleic Acids Res. 1990 Nov 25;18(22):6531-5. 

Anexos 



\section{ANEXO 1}

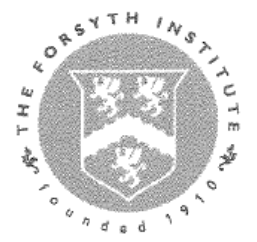

THE FORSYTH INSTITUTE

Institutional Review Board FWA 00000398

August 8, 2006

Dear Dr. Tanner,

Your submission to conduct research with samples from human subjects in the study Longitudinal study of transmission, diversity, and stability of Streptococcus mutans in Brazillian families is hereby approved. The Forsyth IRB has issued this protocol the number 06-11. Full board review is not required.

You will have to report all plans to make changes in the research protocol and/or consent form to the IRB, and you are not to make changes without IRB approval. This requirement will be waived only if it becomes necessary for you to eliminate immediate risk to the subjects, and the IRB must be notified of these changes as quickly as possible.

The IRB would also like to remind you that subjects who do not speak English should be presented with a consent document written in a language understandable to them. Alternately, the consent form can be presented orally, with a written summary of what is orally communicated. If the form is presented orally, a translator who is fluent in both English and the language of the subject should sign the summary document.

The IRB must be advised immediately, within 5 days, of emergent problems in the use of human subjects, including significant hazards, contraindications, or side effects of procedures. The IRB will report problems and changes in protocol to Institutional, State, or Federal authorities, as necessary.

Should you decide to advertise for the purpose of recruiting subjects for this study, you will need to submit a copy of your proposed advertisement to the IRB for review and approval prior to distribution.

The last day of approval on this application is August 7, 2007. If it becomes an ongoing project, you must return the Annual Status Report that will be sent to you, indicating that this is a continuing project for renewed approval. Thank you for presenting your protocol to the Forsyth IRB.

Sincerely yours,

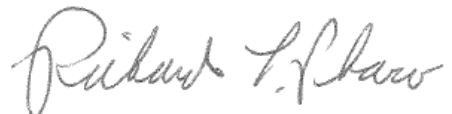

Richard L. Pharo, ScD

Chair, Forsyth Institute IRB 

MINISTERIC) UA SAUDE

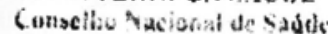

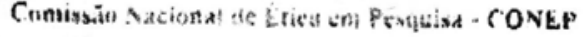

\section{PARECER N $N^{\circ} 810 / 2000$}

Processo $n^{\circ}$ 26000.013236/00-38

Registro CONEP $=1378$

Projeto de Pesquisa: 'Prevençăo cia Transmissảo do Estraptococos Mutans de mae para fitho Pesquisator Responsavel: Dre. Odila Perarra da Silva Rosa

Instituiçá Faculdade de Odontologie de beun! Liniverxidede de São Pauio

Área Temática Especial: Pesquisa com coops:açáo estrangeira.

AO se proceder a analise do protocolo em questảo cabem as seguintes comsideraçōes.

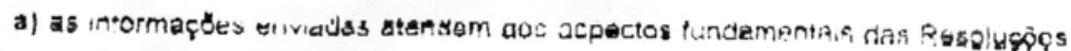
CNC $106 / 050$ 202/58. sodre Diretrizas a Normes Requlamentadoras de Pescuisas Envolvendo Sares Humanos:

b) o projeto fo aprovado paio Comte de Etica arn Pesquise - CEg ag instituiçáo supracitada

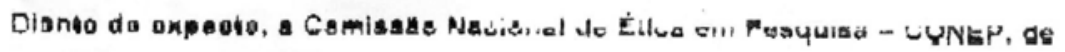
asordo com as atribulçós definidas na Res. CNS 196/96, manlfesta - se pela aprovacho do projeto de pesquisa proposto, com a seguinte recomendaçāo a ser acompanhada pelo CEP :

- Incluir o nome a telefone de contato do pesquisador no Termo de Consentimento Livre Esciarecico $\theta$ envar zo CaP a versão com 0 adenco solieitado

Situaço : Projeto aprovato com recomendaçăo

Brasilia, 2:2 de setembro oe 2000

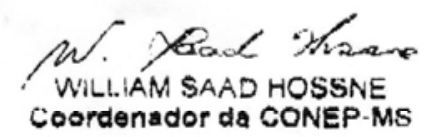





\section{University of Pittsburgh}

\author{
Institutional Review Board \\ MEMORANDUM
}

TO:

FROM: $\quad$ Philip Troen, M.D., Chair P.T/PC

DATE:

December 22, 1999
3500 Fith Avenue
Ground Level
Pittsburgh, PA 15213
412.578.3424
Fax: $412-578-8553$

SUBJECT: IRB\#990357: Prevention of Transmission of the Mutans Streptococci from Mother to Child

Thank you for addressing the concems of the Institutional Review Board regarding the above-rcferenced proposal. This version of your proposal has been approved. This protocol has been designated by the Board as a miximal risk protocol. Therefore, unless there is a substantial change in risk during the next renewal interval, this protocol can be expedited at its next renewal.

\section{Approval Date: December 22, 1999 \\ Expiration Date: December 22, 2000}

Plcase type the approval date on the upper right-hand comer of the consent form before copies are made for subjects to sign. The original signed consent form should be retained for the research records; a copy should be made for the medical chart (if the subject is an in-patient); and a copy should be given to the subject.

Adverse events which occur during the course of the research study must be reported to the IRB Office. Please call the IRB Adverse Event Coordinator at 578-8569 for the current policy and forms.

The protocol and consent forms, along with a bricf progress report must be resubmitted at least one month prior to the expiration date noted above for annual renewal as requircd by Assurance No. M1259, given to DHHS by the University of Pittsburgh.

If your research proposal involves an investigational drug, please forward a copy of this approval letter along with a copy of the Cover Sheet, protocol consent form(s) and drug brochure to Investigational Drug Servicc, PUH Pharmacy.

Please be advised that your research study may be audited periodically by the University of Pittsburgh Research Conduct and Compliance Office.

PT/pc 



\section{UNIVERSIDADE DE SÃO PAULO \\ FACULDADE DE ODONTOLOGIA DE BAURU \\ Al. Dr. Octávio Pinheiro Brisolla, 9-75 - Bauru-SP - Brasil - CEP 17043-101 \\ C.P. 73 - PABX (014) 235-8000 - FAX (014) 223-4679}

\section{COMITÊ DE ÉTICA DE PESQUISA}

Bauru, 08 de novembro de 1999

Senhora Professora

O projeto de pesquisa encaminhado a este COMITE DE ÉTICA denominado "Prevenção da Transmissão de Estreptococos Mutans de Mães para. Filhos", a ser desenvolvido pela Dr' Odila Pereira da Silva Rosa, Dr. Sergio Aparecido Torres, Dr. Walter A. Bretz (Coordenador), Dr. Walter Loesche e Dra Lisa Weissfeld, foi encaminhado ao Relator para ser analisado do ponto de vista ético.

Na reuniào de 28 de outubro p.p. o parecer do relator foi julgado pelo Comitê que o aprovou, considerando não existir questōes éticas pendentes. Entretanto, como se trata de pesquisa com participaçào estrangeira, o projeto deverá ser encaminhado por este Comitê para a Comissão Nacional de Ética em Pesquisa, de acordo com o item VIII, 4, letra C, número 8 da Resolução 196/96.

Atenciosamente,

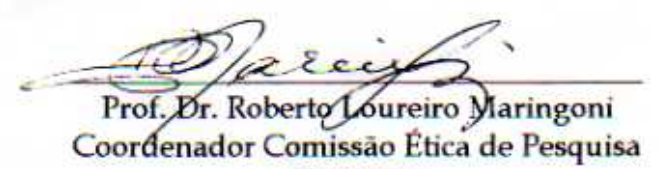
FOB-USP

$\mathrm{Ilm}=\mathrm{Sr}$

Profe Drit, Odila Pereira da Silva Rosa

DD. Docente da Disciplina de Microbiologia e Imunologia FOB-USP 



\title{
ANEXO 2
}

\section{Universidade de São Paulo}

Faculdade de Odontologia de Bauru

Al. Dr. Octávio Pinheiro Brisolla, 9-75 - Bauru-SP - CEP 17012-901 - C.P. 73

PABX (0XX14)235-8000 - FAX (0XX14)223-4679

\author{
CONVÊNIO USP - PITTSBURGH \\ e-mail: convpit@fob.usp.br - Fone: (0xx14)3235-8313
}

Faculdade de odontologia de Bauru - USP Comissăo Nacional de Etica em pesquisa

Parecer $n^{\circ} 810 / 2000$

\author{
University of Pittsburg IRB 990357 \\ National Institute of Dental and Craniofacial \\ Reserch \\ Protocolo na: DE13534 \\ Comitê de Ética da UP \\ Data da aprovaçấ: 05/11/2002 \\ Data da renovaçấo: 05/11/2003
}

\section{CARTA DE INFORMAÇÃO AO SUJEITO DA PESQUISA}

TíTULO DO ESTUDO: Aquisição de estreptococos mutans e anaeróbios periodontopatógenos por primogênitos. Resultados preliminares

RESPONSÁVEL: FOB-USP / National Institute of Dental and Craniofacial Research

PRINCIPAL INVESTIGADOR: Dr. Walter A. Bretz, DDS, MPH, Dr. PH

Assistant Professor

University of Pittsburgh

School of Dental Medicine

3501 Terrace Street

Pittsburgh, PA 15261

Tel: $412-6488087$

CO-INVESTIGADORES: Dra. Odila P.S. Rosa, DDS, PhD

Universidade de São Paulo

Faculdade de Odontologia de Bauru

Sede do Convênio

Bauru, São Paulo, Brasil

Tel: 014-235 8313

LOCALIZAÇÃO: Universidade de São Paulo-Bauru, Faculdade de Odontologia de Bauru, São Paulo, Brasil

Esta forma de consentimento pode conter palavras que você não entenda. Por favor pergunte aos investigadores do estudo ou alguém responsável envolvido com o estudo para explicar qualquer tipo de informação ou palavras que você não entenda.

Para quem você poderia telefonar?

Para fazer perguntas sobre o estudo e sua experiência dentro do estudo, contactar:

Luciana Zanon Fontes Lozano (Secretária do Convênio)

Tel: $014-32358313$ 



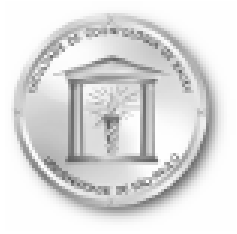

Universidade de São Paulo

Faculdade de Odontologia de Bauru

Al. Dr. Octávio Pinheiro Brisolla, 9-75 - Bauru-SP - CEP 17012-901 - C.P. 73

PABX (0XX14)235-8000 - FAX (0XX14)223-4679

\author{
CONVÊNIO USP - PITTSBURGH \\ e-mail: convpit@fob.usp.br - Fone: (0xx14)235-8313
}

Para apresentar reclamaçöes em relaçăo a sua participação na pesquisa, contactar: Comitê de Ética em Pesquisa em seres Humanos da FOB-USP:

Al. Dr. Octávio Pinheiro Brisolla, 9-75 (Sala no prédio da Biblioteca, FOB-USP) ou pelo telefone 3235-8358

\title{
DESCRIÇÃO E PROPOSTA DO ESTUDO
}

Este é um estudo de pesquisa na área odontológica. A proposta deste estudo é investigar a similaridade dos germes que causam a cárie dental, chamados de estreptococos mutans, nas mães, pais e em um agregado quando houver. Sua esposa (ou parente) vem participando da pesquisa desde que seu bebê tinha 2 meses e meio de vida, e continuará a participar até que ele tenha 4-5 anos para avaliarmos o efeito de procedimentos preventivos sobre a transmissão dos germes para o bebê e o desenvolvimento de cárie. Pela convivência íntima do núcleo familiar existe a possibilidade de encontrarmos os mesmos microrganismos em outros membros da família não submetidos aos mesmos procedimentos da mãe, sendo, portanto de interesse o seu exame. Quanto mais soubermos sobre a distribuiçäo desses estreptococos nas famílias, melhor se tornará o planejamento preventivo para evitar que eles colonizem cedo a boca do bebê e provoquem mais cárie. Quinze pais e um agregado, quando houver, farão parte deste estudo na Faculdade de odontologia de Bauru - Universidade de São Paulo.

Se você concordar em participar deste estudo, deverá comparecer à Faculdade de Odontologia de Bauru a cada 4 meses, por um periodo de 2 anos para os seguintes procedimentos:

1) Responder a um questionário sobre a sua saúde geral.

2) Submeter-se a um exame clínico visando detectar a presença de cárie dental e inflamação gengival.

3) Submeter-se ao exame radiográfico de boca (no exame inicial e final).

4) Fornecer uma amostra de saliva colhida da seguinte maneira: mastigando uma goma base sem açúcar, cuspir numa placa estéril, mantida num isopor com gelo, por 5 minutos. 



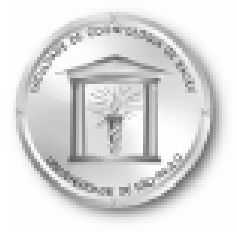

\section{Universidade de São Paulo}

Faculdade de Odontologia de Bauru

Al. Dr. Octávio Pinheiro Brisolla, 9-75 - Bauru-SP - CEP 17012-901 - C.P. 73

PABX (0XX14)235-8000 - FAX (0XX14)223-4679

CONVÊNIO USP - PITTSBURGH

e-mail: convpitcofob.usp.br - Fone: (0xx14)235-8313

Observạ̧ōes:

1) Cada visita terá duração em torno de 40 minutos.

2) Nenhum tratamento dentário lhe será oferecido durante o período do estudo. Todavia, receberá informação sobre as condiçöes de sua boca e orientação sobre a clínica da Faculdade que deverá procurar em caso de necessidade.

3) Sempre que comparecer receberá atestado que comprove sua ausência ao trabalho.

\section{RISCOS E BENEFÍCIOS}

Não existe nenhum risco associado com a coleta de saliva.

Participação nesta pesquisa envolve exposição a radiação com radiografias de boca toda (técnica de bitewing). Isto corresponde a $1,8 \mathrm{mrems}$ de radiação durante todo o estudo com mínima exposição para outras partes do corpo. Por exemplo, trabalhadores que trabalham com radiação são permitidos por lei um máximo de radiação de 50 rems por ano para qualquer parte do corpo. Os riscos associados a radiação (alteração celular ou câncer), pela baixa quantidade de exposição que você receberá neste estudo são consideradas baixas e semelhantes aos riscos diários provenientes de radiaçäo natural.

\section{COMPROMISSO COM O ESTUDO}

A participação na pesquisa envolverá um periodo de 2 anos.

\section{NOVA INFORMAÇÃO}

Você será imediatamente notificado de qualquer nova informação que aparecer neste estudo que poderá fazer você mudar de idéia em relação a continuar nele.

\section{CUSTOS/PAGAMENTOS}

Não haverá despesas para você pelas visitas. Você será reembolsado pelo tempo, locomoçäo e outras despesas com $\mathrm{R} \$ 30,00$ por visita. 



\title{
Universidade de São Paulo
}

Faculdade de Odontologia de Bauru

Al. Dr. Octávio Pinheiro Brisolla, 9-75 - Bauru-SP - CEP 17012-901 - C.P. 73

PABX (0XX14)235-8000 - FAX (0XX14)223-4679

\author{
CONVÊNIO USP - PITTSBURGH \\ e-mail: convpit cofob.usp.br - Fone: (0xx14)235-8313
}

\section{INDENIZAÇÃO POR INJÚRIA}

Se for constatado que você teve uma injúria decorrente deste estudo, a Universidade de São Paulo em Bauru irá providenciar tratamento necessário. A Universidade de Säo Paulo näo proporcionará qualquer outra recompensa relacionada com esta injúria. Em caso de injúria favor entrar em contato com a Dra. Odila Rosa no telefone 014-235 8313.

\section{PRIVACIDADE}

Todos os arquivos relacionados com esta investigação seräo armazenados em um arquivo confidencial na Sede do Convênio na Faculdade de Odontologia de Bauru da Universidade de Säo Paulo e na University of Pittsburgh, School of Dental Medicine, 3021 Salk Annex, com o Dr. Walter Bretz. Sua identidade será indicada nos arquivos através de números. Só terăo acesso a essas informações os investigadores listados na primeira página deste documento.

Você entende que toda e qualquer informação sobre você seräo contidas em um departamento seguro e confidencial como acontece com arquivos médicos. Você não será mencionado em nenhum tipo de publicação ou resultados da pesquisa. No entanto em casos pouco comuns os resultados da pesquisa poderão ser inspecionados por agências do governo ou utilizadas para processos juridicos. O Comitê de Ética da Universidade de Pittsburgh pode inspecionar os arquivos da pesquisa. É conduta da Universidade de Pittsburgh requerer que todos os arquivos deste estudo sejam guardados pelo menos 5 anos após o término de estudo.

\section{DIREITO DE DESISTÊNCIA}

Você entende que você não é obrigado a participar deste estudo e que poderá mudar de idéia e desistir de participar deste estudo a qualquer hora. Todos os cuidados e benefícios serão da mesma forma mantidos quer você participe ou não do estudo. Você não tem nenhuma obrigaçäo de participar desta pesquisa. 



\title{
Universidade de São Paulo
}

Faculdade de Odontologia de Bauru

Al. Dr. Octávio Pinheiro Brisolla, 9-75 - Bauru-SP - CEP 17012-901 - C.P. 73

PABX (0XX14)235-8000 - FAX (0×X14)223-4679

\author{
CONVÊNIO USP - PITTSBURGH \\ e-mail: convpit@fob.usp.br - Fone: (0xx14)235-8313
}

\section{ELIMINAÇÃO DA PESQUISA}

Você poderá ser eliminado do estudo se não comparecer às consultas agendadas sem justificativa ou se não colaborar com as instruçōes dadas pelos investigadores.

\section{CONSENTIMENTO VOLUNTÁRIO}

Tudo me foi explicado acima e não tenho nenhuma dúvida. Eu entendo que qualquer dúvida futura que eu tenha sobre este estudo será respondida pelos investigadores listados na primeira página deste documento através dos telefones dados. Quaisquer perguntas que eu tiver dos meus direitos como participante desta pesquisa serão respondidas pelo Human Subject Protection Advocate, University of Pittsburgh (412-5788570) e pelo Comitê de Ética da Faculdade de Odontologia de Bauru da Universidade de São Paulo (014-32358356). Ao assinar esta forma eu consinto em participar desta pesquisa.

Assinatura do Participante

Data

\section{CERTIFICAÇÃO DO INVESTIGADOR}

Eu certifico que a natureza e o propósito, os beneficios potenciais e riscos, associados com a participação nesta pesquisa foram explicados para a pessoa mencionada acima e que quaisquer perguntas foram respondidas adequadamente. 

Universidade de São Paulo

Faculdade de Odontologia de Bauru

Al. Dr. Octávio Pinheiro Brisolla 9-75 - Bauru-SP - CEP 17012-901 - C.P. 73

PABX (0XX14)235-8000 - FAX (0XX14)223-4679

\section{TERMO DE CONSENTIMENTO LIVRE E ESCLARECIDO}

Pelo presente instrumento que atende às exigências legais, o Sr. (a)

portador da cédula de identidade _, após leitura minuciosa da CARTA DE INFORMAÇÄO AO PACIENTE, devidamente explicada pelos profissionais em seus mínimos detalhes, ciente dos serviços e procedimentos aos quais será submetido, não restando quaisquer dúvidas a respeito do lido $e$ explicado, firma seu CONSENTIMENTO LIVRE E ESCLARECIDO concordando em participar da pesquisa proposta.

Fica claro que o paciente ou seu representante legal, pode a qualquer momento retirar seu CONSENTIMENTO LIVRE E ESCLARECIDO e deixar de participar desta pesquisa e ciente de que todas as informações prestadas tomaram-se confidenciais e guardadas por força de sigilo profissional (Art. $9^{\circ}$ do Código de Ética Odontológica).

Por estarem de acordo assinam o presente termo.

Bauru-SP, de de. 



\section{ANEXO 3}

\section{Equipamentos}

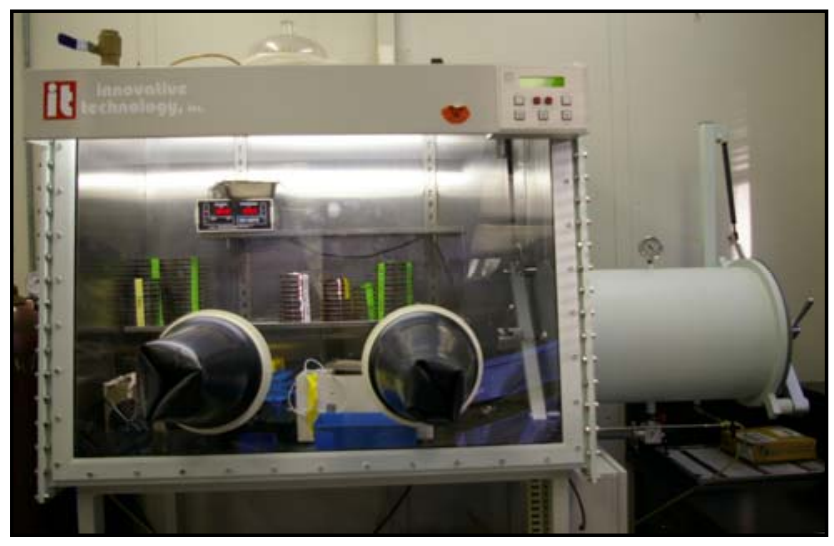

Câmera de Anaerobiose (Innovative Technology Inc.)

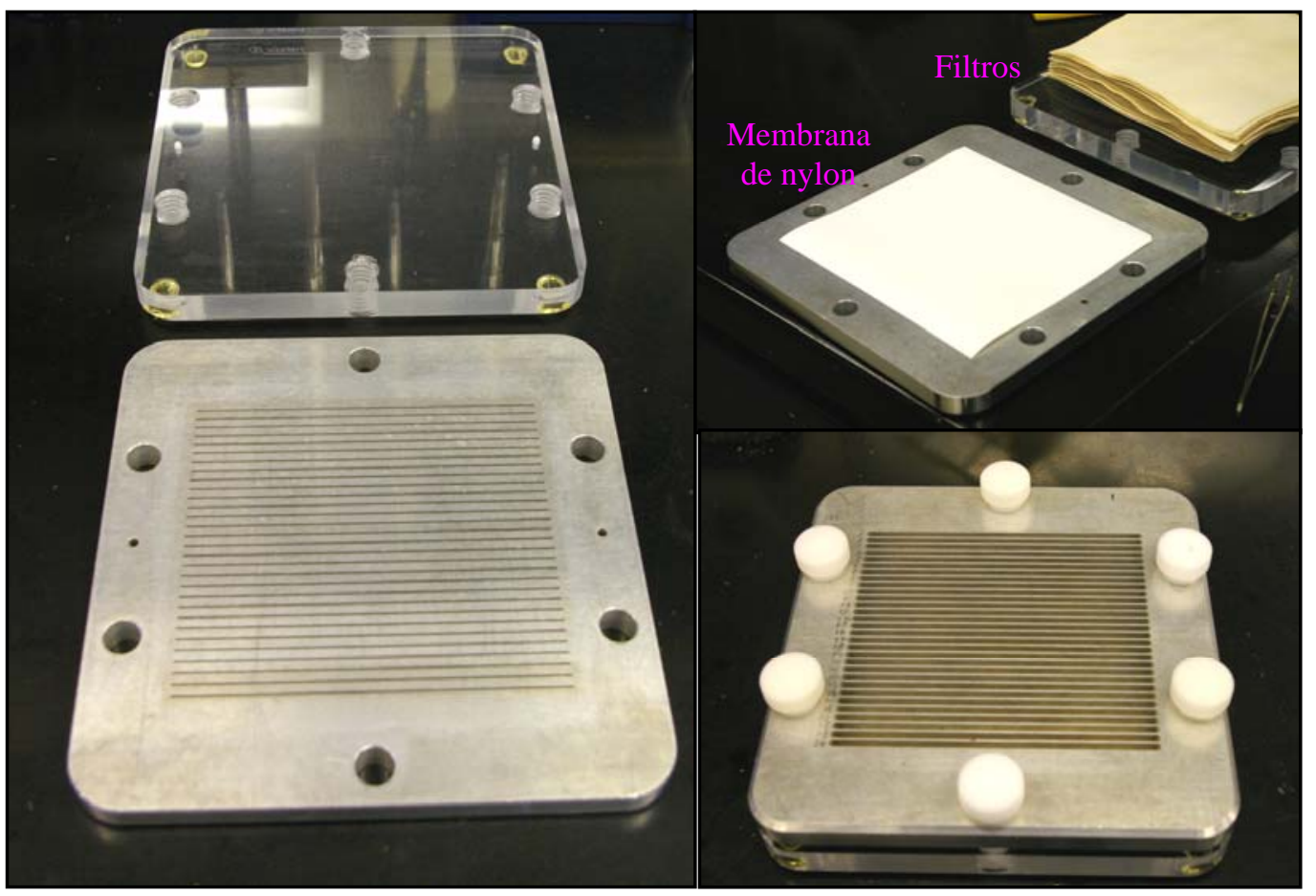

Minislot 30 (Immunetics) 



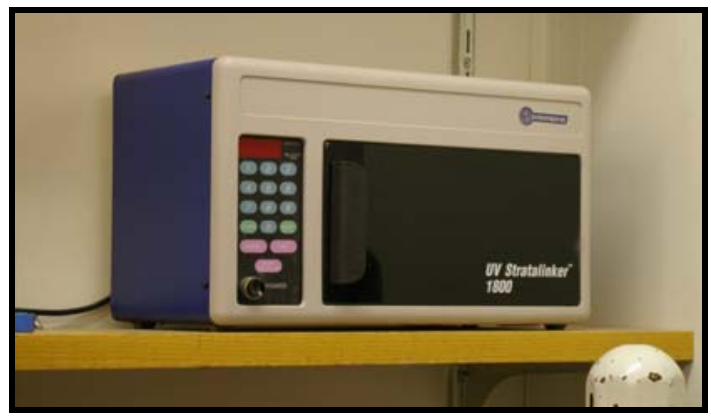

Câmara de Ultravioleta ( Stralinker® 1800)
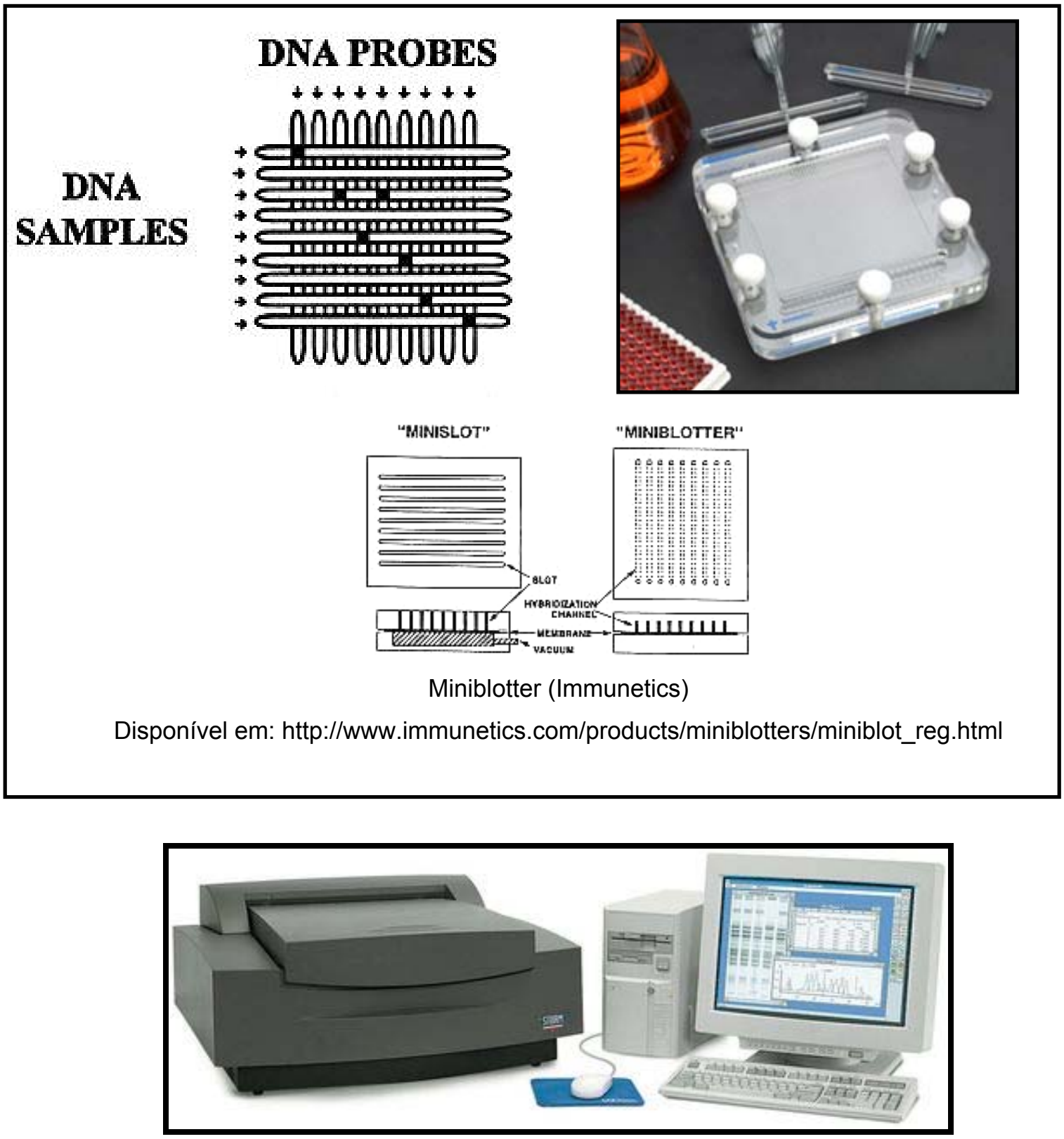

Storm 860 Gel escâner laser de fluorescênica (Molecular Dynamics, GE)

Disponível em:

http://www6.gelifesciences.com/aptrix/upp01077.nsf/Content/Products?OpenDocument\&parentid=286 927\&moduleid=163723\&zone=\#content 



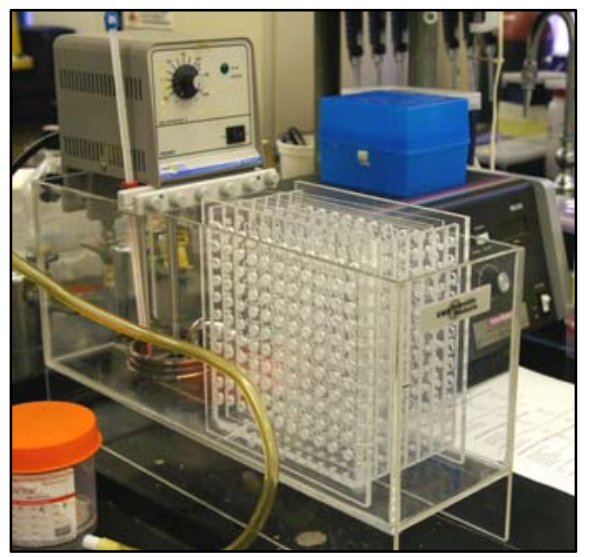

Disk Wisk (Schleicher e Schuell)

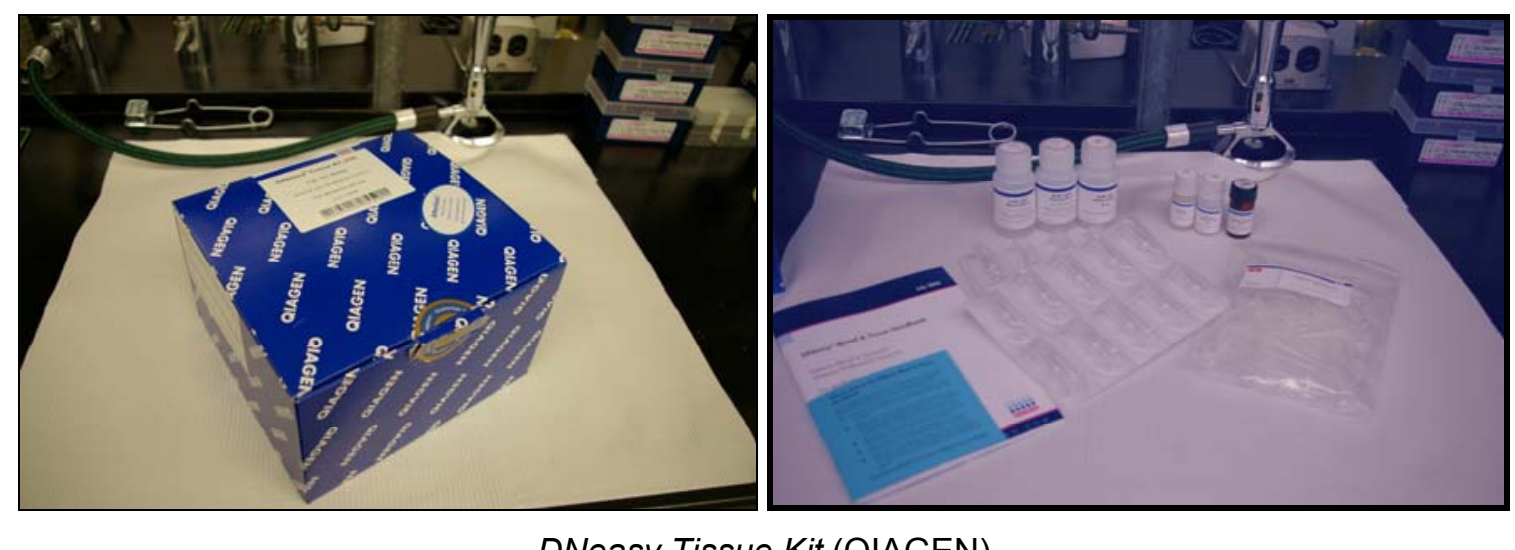

DNeasy Tissue Kit (QIAGEN)

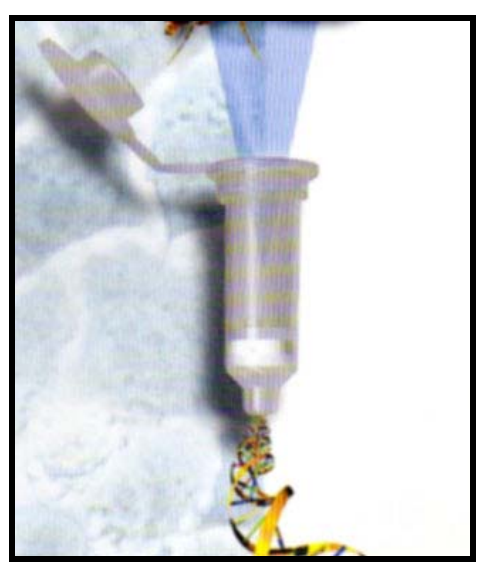

(DNeasy spin column) com um filtro (DNeasy membrane) 



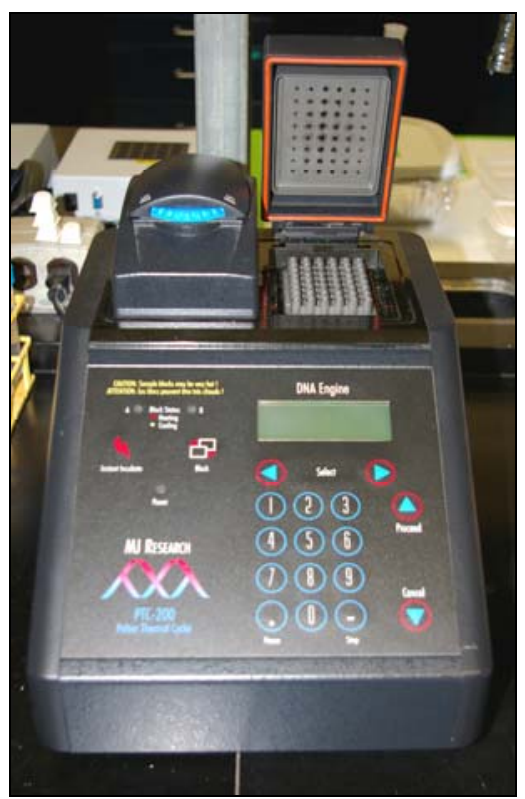

Termociclador (PTC 200 Thermal Cycler)

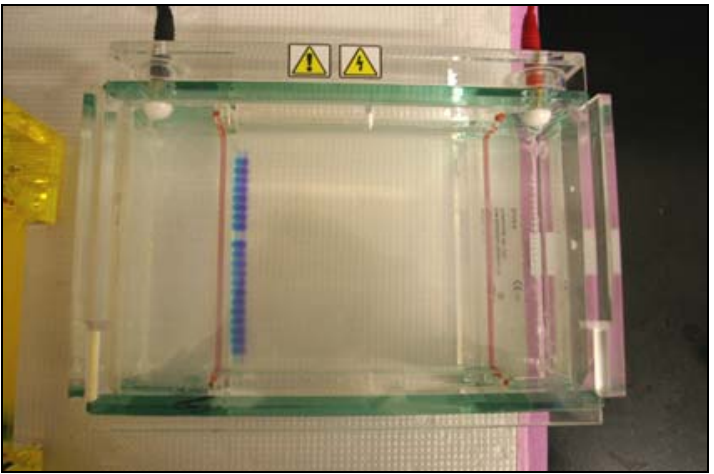

EasyCast $^{\mathrm{TM}}$ Mini Gel Electrophoresis System

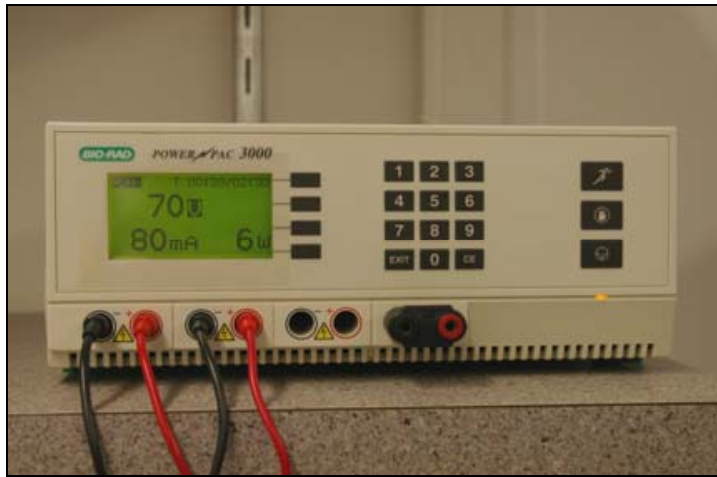

Power Pac 3000 (BIO-RAD)

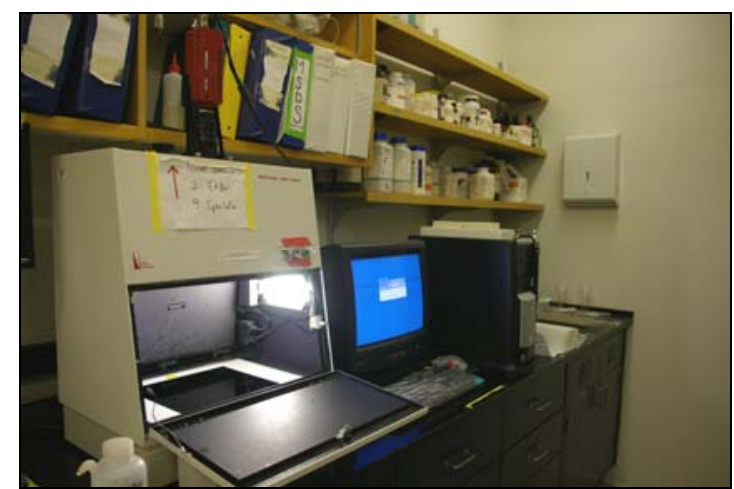

Multimage Light Cabinet ( Alpha Innotech Co) 